AFG/89/580

Afghanistan Drug Control and Rehabilitation Programme PESHAWAR

- List of Publications in ADCRP Library

- List of Publications in ADCRP Library (Subject EDUCATION)

- List of Publications in ADCRP Library (Subject DRUGS)

- List of Publications in ADCRP Library (Subject TRAINING)

- Subject List for ADCRP Library 


\section{LIST OF PUBLICATIONS IN ADCRP LIBRARY}

ACCESSION NO(s) FROM: 1 TO: 615

Subject No: 371.1 Author:

Title of the 10 steps to help your child say "no" : a parents guide / NIAAA Pub. No: 381

Publication

Subject No: 630

Author: SCA

Title of the 1988 and 1989 surveys / Swedish Committee for Afghanistan

Publication

Subject No: 633.79 Author: Cannabis Investigations Section

Title of the 1989 domestic cannabis eradication suppresion program / Cannabis

Publication Investigation section

Subject No: $630 \quad$ Author: SCA

Title of the 1990 survey / Swedish Committee for Afghanistan

Pub. No: 170

Publication

Subject No: 361.7706 Author: UNDP

Title of the 1991 Annual report : The challenge of the environment / UNDP

Pub. No: 357

Publication

Subject No: $363.45 \quad$ Author: USIS

Title of the 1993 International Narcotics control strategy - Europe

Publication

- Pub. No: 581

Subject No: $361.77 \mathrm{M}-$ Author: Operation Salam
Title of the 3 days in Southern Nangarhar 27-29 March 1990 / Operation Salam

publication

Subject No: $371.1 \quad$ Author: UNO

Title of the A brief description of the manpower training program / Education

Publication sector support Project

Subject No: 362.29 - Author: Harrison-Burns, Bettye

Pub. No: 378

Title of the

Publication

A guide to multicultural drug abuse prevention

Subject No: 338.9 - Author: Hansen, John R.

Pub. No: 199

Title of the

A guide to the guidelines : The UNIDo method of economic project

Publication

evaluation / John R. Hansen

Subject No: 362.292 Author: Winger, Gail

Title of the A handbook on drug and alcohol abuse : The biomedical aspects /

Publication Gail winger

Subject No: 362.293 - Author: Doin, Nicholas \& South, Nigal (editors) - Pub. No: 83

Title of the A land fit for heroin? : Drug policies, prevention and practice

Publication / edited by Nicholas Doin and Nigal South

Subject No: $361.77 \mathrm{M} \longrightarrow$ Author: Garner, David

Title of the A monitoring and evaluation capacity for the UNDP / David Garner

Publication

Subject No: 615

Author: Julien, M.Robert

Pub. No: 403

Title of the

Publication

A primer of drug abuse / Robert M. Julien

- Pub. No: 127

Produced on $30 / 01 / 94$ at $15: 02: 27$

Page: 1 
ACCESSION NO(s) FROM: 1 TO: 615

Subject No: 633.75 - Author: Brailsford, Guy (comp). Pub. No: 10

Title of the A survey of opium cultivation in Badakshan Province, Afghanistan

Publication / compiled by Guy Brailsford

Subject No: 361.7706 Author: ACBAR

Title of the ACBAR annual report 1989 - / ACBAR

Pub. No: 157

Publication

Subject No: $060 \quad$ Author: ACBAR

Title of the / ACBAR directory of members / ACBAR

Publication

Subject No: 362.29 Author:

Title of the AD HOc task force recommendations on alcohol and other drug abuse Publication $\mid /$ OSAP

Subject No: 025.3Ref Author: American Library Association

Title of the ALA filing rules / ALA

Publication

Subject No: 016 Ref - Author: ARIC

Pub. No: 377

Title of the ARIC bulletin 1990 - / ARIC

Publication

Subject No: 362.29 Author: wHO

Title of the Action to reduce substance abuse / WHO

Pub. No: 106

Publication

Subject No: 651.1 - Author: Finnegan, John

Title of the / Addictions : A nutritional approach to recovery / John Finnegan

Publication

Subject No: 615.1 - Author: Fleming, Michael F.

Pub. No: 429

Title of the Addictive disorders / Michael F.Fleming

Publication

Subject No: 362.29 Author: Sherouse, L.Deborah

Title of the Adolescent drug and alcohol abuse handbook : For parents and

Pub. No: 495

Publication professionals / Deborah L.Sherouse

Subject No: 363.194 - Author: Shedler, Jonathan

Title of the Adolescent drug use and psychological health / Jonathan shedler

Publication

Subject No: 362.298 - Author: Arif, A. (ed)

Pub. No: 549

Title of the Adverse health consequences of cocaine abuse / wHo

Publication

Subject No: 361.7706 Author: ADA

Pub. No: 473

Title of the Afghan development association

Publication

Subject No: 361.7706 Author: ADA

Title of the Afghan development association : six month technical progress

Publication report 
ACCESSION NO(s) FROM: 1 TO: 615

Subject No: $630 \quad$ Author: AASSP - PSA

Title of the Afghanistan 1992 wheat production survey : Baikh and Jawzjan Pub. No: 504

Publication provinces / AASSP - PSA

Subject No: 958.1 Author: Thomas, Jane Murphy Pub. No: 279

Title of the Afghanistan : A forgotten war / Jane Murphy Thomas

Publication

Subject No: 910.3 Author: Helms, L.Roger (ed)

Title of the Afghanistan : Districts and codes by Piovince/Roger I. Helms, Publication editor

Subject No: 361.7706 Author: UNOCA

Title of the Afghanistan : Operation Salam programme for 1992 / UNOCA

Publication

Subject No: 361.7706 Author: UNOCA

Title of the Afghanistan : Operation Salam report for 1991 / UNocA

- Pub. No: 150

Publication

Subject No: 361.7706 Author: UNOCA

Title of the Afghanistan : Progress report on operation Salam Programme,

Publication Jan - Jun 1992 / UNOCA

Subject No: 361.77M Author: Fort, Raymond E.

Title of the Afghanistan : Report of the evaluation mission / Raymond E. Fort,

Publication Abdul Ferough, Johan Fagerskiold

Subject No: 361.77PD - Author: UNFDAC

Title of the Afghanistan : Semi-annual report on country assistance

Publication implementation / UNFDAC

Subject No: 958.1 Author: AMRC

Title of the Afghanistan : The Cost of freedom / Afghan Media Resource Centre

Publication

Subject No: 958.1 Author: Jawad, Nassim

Title of the Afghanistan : a nation of minorities / by Nassim Jawad

- Pub. No: 152

Pub. No: 148

Publication

Subject No: 958.1 Author:

Title of the Afghanistan energy and natural resources / author unknown

- Pub. No: 263

Publication

Subject No: 362.0425 Author: UNDP

Title of the Afghanistan rehabilatation strategy : Agriculture and irrigation

Publication / UNDP Kabu1 Afghanistan

Subject No: 362.0425 Author: UNDP

Title of the Afghanistan rehabilitation strategy : Annexes / UNDP Kabul Afg

Publication

Subject No: 362.0425 Author: UNDP

Title of the Afghanistan rehabilitation strategy : National context / UNDP

Publication Kabul Afghanistan 
ACCESSION NO(s) FROM: 1 TO: 615

Subject No: 362.0425 Author: UNDP

Title of the Afghanistan rehabilitation strategy : Overview / UNDP Kabul - Afg

Publication

Subject No: 362.0425 - Author: UNDCP

Title of the Afghanistan rehabilitation strategy : social services / UNDP

Publication Kabul Afghanistan

Subject No: 362.0425 Author: UNDP

Title of the Afghanistan rehabilitation strategy : Transport and communication

Publication / UNDP Kabul Afghanistan

Subject No: 362.0425 Author: UNDCP

Title of the Afghanistan rehabilitation strategy : executive summary / UNDCP

Publication Kabul - Afghanistan

Subject No: 362.0425 Author: UNDP

Title of the Afghanistan rehabilitation strategy ; commerce and industry /

Publication UNDP Kabul Afghanistan

Subject No: 361.7706 Author: UNDP

Title of the Afghanistan rural rehabilitation \& reconstruction : 1991 project

Publication summay report / UNDP

Subject No: 361.7706 Author: UNFDAC

Title of the Afghanistan semi-annual report on country assistance

Publication implementation, June to December 1989 / UNFDAC

Subject No: 361.7706 Author: Afghanaid

Pub. No: 462

Title of the Afghanistan towards rebuilding a shattered country / by Afghanaid

Publication

Subject No: 630

Title of the

Publication

Author: AASSP - PSA

Pub. No: 505

Afghanistan wheat planning survey $1992 / 93$ : Helmand, Kandahar,

Ghazni, and Herat provences / AASSP - PSA

Subject No: 635 Author: DAI - ASSP

Title of the Afgnistan crop potential series bulletin / DAI-ASSP

Pub. No: 214

Publication

Subject No: 338.1 - Author: DAI

Title of the Agricultural resource inventory : saidabad, Wardak / DAI

Publication

Subject No: $\mathbf{6 3 0}$

Author: DuBIios, Random Pub. No: 516

Title of the Agricultural sustainability : Provincial perceptions in Pakistan

Publication / Random DuBois and David Gow

Subject No: 639.9 - Author: Bradford, Lester Ezar

Pub. No: 215

Title of the Agroforestry in Afghanistan / prepared by Lester Ezar Bradford

Publication

Subject No: 025.3Ref - Author: Curley, Arthur

Title of the Akers simple library cataloging / by Arthur Curley and

Publication

Jana Varlejs 
Subject No: 362.29 - Author: Erikson, Are

Title of the Alcohol and drugs : Perspectives, prevention and control -

Publication Asia Pacific region / edited by Are Erikson, Dayala Abeysekera,

Subject No: 362.292 - Author: Cook, Paddy Shannon

Title of the Alcohol, tobacco, and other drugs may harm the unborn / Paddy

Publication Shannon cook

Subject No: 613

Title of the

Publication
Author: Williams, Glen

All fo health : a resource book for Facts for life
Subject No: 630

Title of the

Publication
- Author: Potulski, Nicole

Alternative crops for drug - growing areas in Asia(Pakistan,

Afghanistan, Nepal, Thailand) / Nicole Potulski

Subject No: 630

Title of the

- Author: Potulski, Nicole

Pub. No: $\$ 33$

Publication

Alternative crops for drug-growing areas in Asia (Pakistan,

Afghanistan, Nepal, Thailand

Subject No: $016 \quad$ Author: OSAP

Title of the American Indians and native Alaskans : A prevention resource

Publication guide / osap

Subject No: 361.77M Author: De Bures, Alain

Title of the An evaluation mission to the Panjshir Valley/Alain De Bures,

Publication John Mc Gill, Abdul gadeer [et.al.]

Subject No: 615.1 Author: Cahalan, Don

Title of the An ounce of prevention : strategies for solving tobacco, alcohol,

Publication and drug problems / Don Cahalan

Subject No: 910.202 Author: Goulet, Leo

Title of the Anaccount of a trip to the USA, South Korea, Thailand, Viet Nam,

Publication

Cambodia, Nepal and Hong kong / Leo Goulet

Subject No: 630 Author: Bosch, Albert G.

Title of the Animal husbandry program 1991 / Albert G. Bosch

Publication

Subject No: 361.7706 Author: MADERA

Title of the Annual Report 1992 : Mission for relief of rural economies/

Publication MADERA

Subject No: 361.7706 - Author: SCA

Title of the Annual report 1988 - / SCA

Publication

Subject No: 361.7706 Author: UNFDAC

Title of the Annual report 1990 on UNFDAC assistance to Afghanistan

Publication

Subject No: 361.7706

Author: ICF

Title of the Annual report 1991

Publication 
publication highland : production, handling and utilization to replace opium

Subject No: 635 Author: Tsamparlis, Michael

Title of the Apricot program / prepared by Michael Tsamparlis

Publication

Subject No: 016

Title of the Asian and Pacific Islander Americans : Prevention Resource Guide

Publication $/$ / OSAP

Subject No: $363.45 \quad$ Author: Lintner, Bertil

Title of the / Asian narcotics protected industry / Bertil Lintner

Publication

Subject No: 362.198 - Author: Valadez, Joseph J.

Title of the Assessing child survival programme in developing countries

Publication $\quad$ : Testing lot quality assurance sampling / Joseph J.Valadez

Subject No: 621.3678 Author: US Government

Title of the Assessing illicit narcotics cultivation using imagery-based

Publication survey methods / Us Government

Subject No: 361.77M - Author: Argandona, M.

Title of the Assessment of drug demand reduction activities / M. Argandona,

Publication A. Haworth

Subject No: $363.8 \quad$ Author: Jawad, Nassim

Title of the Assessment of food shortages in Badakhshan / Nassim Jawad

Pub. No: 218

Publication

Subject No: 630

Title of the

- Author: Saari, Eugene E.

Pub. No: 526

Publication

Assessment of wheat production in Afghanistan and

reccommendations for future activities / prepared by Eugene $E$.

Subject No: 362.29 Author: wHo

Title of the / Atlas report / wHo

Publication

Subject No: 361.77PD - Author: ARIC

Pub. No: 51

Title of the Authority for the reconstruction of infrastructure in Afghanistan

Publication / ARIC

Subject No: 958.1 Author: UNIDATA

Title of the Badakhshan Province, Afghanistan : A socio-economic profile

Publication / UNIDATA

Subject No: 307.12 Author: NAC

Title of the | Badakhshan regional programme : Project summary, 1993 / by NAC

Publication

Subject No: 958.1

Author: UNIDATA

Title of the Balkh Province, Afghanistan : A socio - economic profile

Pub. No: 614

Publication

/ UNIDATA 
ACCESSION NO(s) FROM: 1 TO: 615

Subject No: $361.77 \mathrm{M}$ - Author: Tamrat, s.

Title of the Bamian mission report, September 28 - November 16, 1991

Publication / s. Tamrat

Subject No: 958.1
Title of the | Bamyan Province, Afghanistan : A socio-economic profile / UNIDATA

Publication

Subject No: 338.1

Author: DAI

Title of the Bamyan and Parwan Province : trip report / prepared by

Publication Development alternatives, Inc

Subject No: 305.4 Author: The World Bank

Title of the Bangladesh : stategies for enhancing the role of women in

Publication economic development / The World Bank

Subject No: 362.29 Author: George, R.Frank

Title of the Behavioral and biochemical issues in substance abuse/Frank R.

Publication George, Ph.D.

Subject No: 363.45 Author: Tullis, La Mohd

Title of the | Beneficiaries of the illicit drug trade : Political

Publication consequences and international policy at the intersection of

Subject No: 362.298 - Author: Painter, James

Pub. No: 72

Title of the / Bolivia and coca : a study in dependency / by James Painter

Publication

Subject No: 362.29 Author:

Title of the Brochures and pamphlets dealing with agencies, drug abuse

Publication

Subject No: 362.29 - Author: Sherman, Pecki

Title of the Broken heart whole heart, afamily addiction / Pecki sherman

Pub. No: 423

Publication

Subject No: 630

Title of the

Author: Agricultural sector support Project

Pub. No: 238

Publication

Cash crops feasibility study / Agric
Project, Private sector Agribusiness

Subject No: 338.1 - Author: DAI

Title of the Cash crops rehabilitation and development program : Proposal to

Publication expand cash crop production / DAI

Subject No: 060 Author: UNDCP

Title of the | Catalogue of publicity material for Awarness Creation Compagin /

Publication UNDCP

Subject No: 664.024 Author:

Title of the / Cereal processing / UNIFEM

Publication

Subject No: 305.4

Author: Wings, Gunille

Pub. No: 69

Title of the Changes in female attitudes and social well-being preparing for

Publication repatriation : a pilot study in two Afghan refugees villages in 
Subject No: 307.72 - Author: Ali Khan, Imdad

Title of the Changing Patterns of rural leadership and their characteristics

Publication / Imdad Ali Khan

Subject No: 320 Author: Ali Khan, Imdad

Title of the changing image of local representatives in the rural areas

Publication / Imdad Ali Khan, Muhammad Humayun, Rehmat jan

Subject No: $363.45 \quad$ Author: Usis

Title of the / Chemical controls / by usis

Publication

Subject No: 371.1 Author: Darus Salam

Title of the Children's rights at razor's edge / by Darus salam, Institute

Publication of Reconstructive surgery

Subject No: $371.1 \quad$ Author: Darus Salam

Title of the / Children's rights at razor's edge / by Darus salam, Institute of

Publication Reconstructive surgery

Subject No: 362.29 Author: Kinney, Jean

Title of the | clinical Manual of substance abuse / Jean Kinney, MSW

Publication

Subject No: 362.298 Author: Phillips, Joel L.

Title of the Cocaine : The mystique and the Nality / Joel I. Phillips and

Publication Ronald D. Wynne

Subject No: 362.298 Author: Washton, M.arnold

Title of the Cocaine addiction : Treatment, Recovery, and Relapse prevention /

Publication Arnold M.Washton, Ph.D.

Subject No: 362.298 - Author: Bruno, Francesco (ed)

Title of the/ Cocaine today : Its effects on the individual and society/

Publication

Francesco Bruno, editor

Subject No: 621.38418 Author:

Title of the codan HF SSB transceiver service manual

Publication

Subject No: 615.1 Author:

Title of the Cognitive - behavioral coping skill therapy manual

Publication

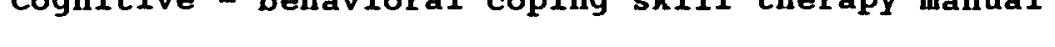

- Pub. No: 129

Subject No: 362.29 Author: Bruno, Francesco

Title of the / combatting drug abuse and related crime / Francesco Bruno

Publication

Subject No: 361.77 Author: United Nations

Title of the Comments of the Administration Committee on coordination on the

Publication report of the Inspection Unit entitled "UN systems cooperation

Subject No: 362.29 Author: United Nations

Title of the Commission on narcotic drugs / UN

Publication 
ACCESSION NO(s) FROM: 1 TO: 615

Subject No: 305.908 Author: Operation Salam Pub. No: 312

Title of the Committee on assistance to disabled Afghans : Guidelines and Publication priorties / Operation Salam

Subject No: 361.7706 Author: Eighmy, Beverly Pub. No: 359

Title of the Commodity export program Afghanistan April/June 30, 1990/ Publication $\mid$ Beverly Eighmy

Subject No: 338.1 Author: Harrington, Tom

Title of the / Commodity price report, april-june 1991 / DAI / ASSP

Pub. No: 229

Publication

Subject No: 025.3Ref Author: Miller, Rosalind E.

Title of the Commonsense cataloging : a cataloger's manual / Rosalind

Publication E. Miller and Jane C. Terivillegar

Subject No: 362.2937 - Author: Arkin, Bralic Elaine \& Funkhouser, E. Pub. No: 54

Title of the

Publication
Communicating about alcohol and other drugs : strategies for reaching populations at risk / Elaine Bralic Arkin, Judith E.

Subject No: 362.2937 Author:

Title of the Communications manual for drug abuse prevention programs

Publication / Asia Near East Regional Norcotics Education Program

Subject No: 371.1 Author: PNCB

Title of the Community intervention against heroin abuse : Trainers manual

Publication / PNCB

Subject No: 362.2937 Author:

Title of the

Community organization guide : A framework for community

Publication involvement in drug abuse prevention / Division of substance

Subject No: 364

Title of the

- Author: UN

Pub. No: 247

Publication

Compendium of United Nations standards and norms in crime

prevention and criminal justice / United Nations

Subject No: 361.7706 Author:

Title of the Comprehensive review of the activities of the United Nations

Publication Fund for Drug Abuse Control in 1990 / UNFDAC

Subject No: 362.29 - Author: Leukefeld, M.Carl \& Tims, M.Frank

Pub. No: 4

Title of the

Compulsory treatment of drug abuse : Research and clinical

Publication practice / editors Carl M. Leukefeld, Frank M. Tims

Subject No: $658.3 \quad$ Author: UNV

Title of the Conditions of service for United Nations volunteers / UNv

Publication

Subject No: 325.21

Author: United Nations

Title of the Consolidated appeal for emergency humanitarian assistance for

Publication

Afghanistan / UN Secretary General

Subject No: 361.7706 Author: UNDP Title of the Consolidated project progress report, twelve month summing of

Publication AFG/88/001 subcontracts, 1991 / UNDP 
ACCESSION NO(s) FROM: 1 TO: 615

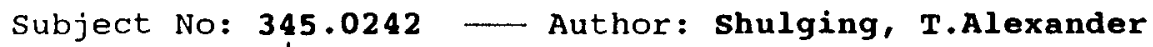

Title of the Controlled substances : Chemical and legal guid to federal drug

Publication laws/Alexandar T.Shulging, Ph.D.

Subject No: 362.29 - Author: Engs, C.Ruth

Title of the controversies in the addiction's field / Ruth c. Engs

Publication

Subject No: 371.1

- Author: UNDCP

Title of the / Core manual on drug orientation / UNDCP

Publication

Subject No: 621.3678 Author: Deekshatulu, L.B.

Title of the | Country report for the meeting of directors of the National

Publication Remote sensing Centers : Programmes in the Escap Region, and 9th

Subject No: 364.177 Author: Henning, Daniel H. Title of the / Country study of Laos / by Daniel H. Henning

Publication

Subject No: $630 \quad$ Author: SCA

Title of the / Crops and yields / Swedish committee for Afghanistan

Pub. No: 161

Publication

Subject No: 621.3678 Author: shroden, John F.

Title of the cross border remote sensing, geographic information septem

Publication mapping, telecommunications and education activities for

Subject No: 025.Ref Author:

Title of the DDC Dewey Decimal classification and relative index / devised

Publication by Melivil Devey

Subject No: 361.7706 Author: DACAAR

Title of the Dacaar 1990 annual report / Danish Committee for Aid to Afghan

Publication $\quad$ Refugees

Subject No: 025.06 Author: ACBAR

Title of the Database of NGo activities / Agency Coordinating Bady for Afghan

Publication Relief

Subject No: 025.06 Author: ACBAR

Pub. No: 609

Title of the Database of NGo activities / Agency Coordinting Body for Afghan

Publication $\mid$ Relief

Subject No: 025.06 Author: ACBAR

Title of the Database of NGo activities/agency Coordinating Boby for Afghan

Publication Relief

Subject No: 362.29 Author: Jackson, Micheal \begin{tabular}{l|l} 
Title of the & Deing drugs \\
Publication &
\end{tabular}

Publication

Subject No: 363.45 Author: Yakos, Marvin

Title of the Deliverance from drugs / Marvin Yakos

Publication 
Subject No: 630 Author: Speedy, Andrew (ed)

Title of the / Developing world agriculture / Andrew speedy, editor

Publication

Subject No: 635

Author: Alam, zahur

Pub. No: 323

Title of the Development of horticulture in mountain regions of Pakistan

Publication

Subject No: 371.1 - Author: Thom Betsy

Title of the Development of materials, Methods and Techniques for drug

Publication

Awareness Creation Campaigns and Women's Training / Betsy Thom

Subject No: 630

- Author: Highland Agriculture Project, Thailand

Pub. No: 37

Title of the Development research on economic ferns as cash crop for the

Publication hilltribes of Northern Thailand : final report / Highland

Subject No: $\mathbf{4 1 3}$ Author: Kumar, Raj \& Anand Satish (editors)

Title of the Dictionary of drugs / edited by Raj Kumar and Satish Anand

Publication

Subject No: 362.29

Author: United Nations

Title of the Die vereinter Nationen und die bekampfung des drogenmissbrauchs

Publication

Subject No: $413 \quad$ Author: Borland, Douglas $M$.

Title of the Digestive drugs/ Douglas $M$. Borland

Publication

Subject No: 060

Author: Thomas, Jane (ed)

Title of the Directory of Afghan NGO's $1991 /$ edited by Jane Thomas

Pub. No: 603

Publication

Subject No: 060

Author: United Nations

Publication / United Nations

Subject No: 060 Author: United Nations

Title of the Directory of the United Nations and specialised agencies

Publication personnel in Afghanistan / UNDP

Subject No: 362.29 Author: Peele, stanton

Title of the Diseasing of America : Addiction treatment out of control/

Publication stanton Peele

Subject No: 362.29 Author: Garrison, Thresa

Pub. No: 390

Title of the Do it with skits : a guide to presenting your prevention program

Publication / Theresa Gassison

Subject No: 361.7706 Author: Operation Salam

Title of the Doner dossien August 1989 / Operation Salam

Publication

Subject No: 364.177 - Author: Singhanetra-Renard, Anchalee

Title of the Draft of $15 \mathrm{July} 1992$

Publication 
Subject No: 362.29 Author: Wish, D.Eric (ed)

Title of the | Drug abuse : linking policy and research / The Annals; special

Publication editor Eric D. Wish

Subject No: 362.29 - Author: Cockett, R.

Title of the | Drug abuse and personality in young offenders / R. Cockett

Publication

Pub. No: 118

Subject No: $362.29 \quad$ Author: Bhandari, Bishnu

Title of the Drug abuse in Nepal : Prevalence prevention, treatment and Pub. No: 373

Publication rehabilitation / Editors, Bishnu Bhandari, Hari Prasad Sarmah

Subject No: 362.2937 Author: Department of Health Bangkok

Title of the Drug abuse prevention and treatment division Annual report/

Publication Dept. of Health Bangkok

Subject No: 616.8918 - Author: Hubbard, L.Robert

Title of the Drug abuse treatment : A national study of effectiveness / Robert

Publication I.Hubbard

Subject No: 615.78 Author: Brady, C.John

Title of the Drug addicts : Are they out of control ?/John C.Brady

Publication

Subject No: 362.299 Author: Walker, I.Bonnie

Title of the Drug and alcohol workbook / Bonnie L.Walker

Publication

Subject No: 361.77 Author: UNDCP

Pub. No: 595

Title of the Drug control and rural rehabilitation : phase - II / UNDCP

Publication

Subject No: 361.7706 Author: Weir Andrew

Title of the Drug control and rural rehabilition in Afghanistan / Andrew

Publication Weir

Subject No: 361.77 PD - Author: UNDCP

Title of the Drug control assistance and resource programme / UNDCP

Publication

Pub. No: 27

Subject No: 362.29 Author: Khan, M. Zaheer

Title of the Drug dependence in Pakistan / M. Zaheer Khan

Publication

Subject No: 362.29 - Author: Zaheer Khan, $\mathbf{M}$.

Title of the | Drug dependence in Pakistan / M.zaheer Khan

Publication

Subject No: 362.2937- Author: Walsh, Peter

Title of the Drug education - a personal development issue : a guide for

Publication Victorian teachers / Peter Walsh, Ruth Freedman, Geoff Munro

Pub. No: 597

Subject No: 362.2917 - Author: Trebach, s.Arnold

Title of the Drug prohibition and the conscience of nations / Arnold s.Trebach

Publication 
Subject No: 362.29 Author: Royal college of Psychiatrists Title of the Drug scenes : a report on drugs and drug dependence / by The Publication Royal college of Psychiatrists

Subject No: 362.29 Author: Maisto, stephen A.

Title of the Drug use and misuse/ stephen A.Maisto

Publication

Subject No: 615.1

Author:

Title of the Drug use and misuse : A reader / open University Milton Keynes

Publication

Subject No: 362.2917

Author: Seymour, B.Richard

Title of the

Drugfree : A unique, positive approach to staying off alcohol and

Publication other drugs / Richard B. Seymour

Subject No: $362.29 \quad$ Author: Hawkes, Nigel

Title of the Drugs / Nigel Hawkes

Publication

Subject No: 362.2917 - Author: Carroll, R.Charles

Title of the Drugs : In modern society/ Charles R.Carroll

Publication

Subject No: 615

Author: Laurie, Peter

Title of the Drugs : medical, psychological and social facts / Peter Laurie

Publication

Subject No: 362.29

Author:

Title of the

Drugs and violence : Causes, correlates, and Consequences / NIDA

Publication

Subject No: 364

Title of the

Author: Cotic, Dusan

Pub. No: 82

Publication

Drugs and punishment : an up-to-date interregional survey on

drug-related offenses / Dusan cotic

Subject No: 363.45 - Author: Kelleher, Maureen E.

Title of the Drugs and society : A critical reader / Maureen E.Kelleher

Publication

Subject No: 362.29 - Author: click, Ronald \& Moore, Joan (editors)

Title of the Drugs in hispanic communities / edited by Ronald Glick and Joan

Publication

Subject No: 362.29 Author:

Title of the | Drugs of abuse : chemistry, pharmacology, immunology, and AIDs /

Publication $\quad$ NIDA

Subject No: 345.0242 Author:

Title of the Drugs, crime, and the Justice system / Bureau of Justice

Publication statistics

Subject No: 362.29 - Author: Rucker, R.D.

Title of the Drugs, drug addiction and drug dealing / R.D.Rucker

Publication 
ACCESSION NO(s) FROM: 1 TO: 615

Subject No: 658.456 Author: ESCAP Pub. No: 598

Title of the Escap Regional Remote sensing Programme

Publication

Subject No: $\mathbf{3 7 0}$ Author: UNEsco

Pub. No: 585

Title of the Educating against drug abuse

Publication

Subject No: 370 Author: UNESCo

Title of the Education for all

Publication

Subject No: $370 \quad$ Author: UNEsco

Title of the Education for all

Publication

Subject No: 615.1 Author: Melear, L. Lawrence

Title of the Educator's guide to drug prevention / Lawrence L.Melear, Ph.D.

Publication

Subject No: 364

Title of the

- Author: United Nations

Publication

Eighth United Nations congress on the prevention of crime and the

Pub. No: 79

treatment of offenders / United Nations

Subject No: 361.7706 Author: ESAR

Title of the Engineering Services for Afghanistan Reconstruction annual

Publication reports 1989 - / ESAR

Subject No: 630

- Author: Altieri, Miguel

Title of the Environmentally sound small scale agricultural projects :

Publication Guidelines for planning / by Miguel Altieri ; edited by

Subject No: 614.4 Author: National Institute on Drug Abuse

Title of the Epidemiologic trends in drug abuse / National Institute on Drug

Publication Abuse

Subject No: 658.7 - Author: UNICEF

Title of the Essential drugs price list, January - June 1989 / UNICEF

Publication

Subject No: 631.7 - Author: Roth, Alan D.

Title of the Evaluation of Mae Chaen Watershed development project / Alan

Publication

D. Roth, Lynn Hewitt, Michael Carroll, Kasem Cheenkao

Subject No: 615.1 - Author: stimmel, Barry

Title of the Evaluation of drug treatment programmes / Barry stimmel

Publication

Subject No: 361.77 Author: Poulin Roger

Title of the Evaluation of the Afghanistan pvo co-financing and rural

Publication assistance projects / Roger Poulin, Richard English, Sharon Fee,

Subject No: 361.77M Author: Floence, Buar

Title of the Evaluation of the mine clearance programme in Afghanistan /

Publication

submitted by Buar Florece and James Freedman 
Title of the Exotic fruit production as a substiture for opium poppy in the

Publication highlands of Thailand : Final report / Highland Agriculture

Subject No: 633.75 Author: PNCB

Title of the Experiences in assessing illicit narcotics crop cultivation / by

Publication

Pakistan Narcotics Control Board

Subject No: 615.1 Author: Chauhan, R.K.

Title of the Expressive drug pictures of materia medica Part 2 / by R.K.

Publication Chauhan

Subject No: 363.45 Author: UN Div. of Narcotic Drugs

Title of the Extradition for drug-related offences : a study of existing

Publication

extradition practices, suggested guidelines for use in

Subject No: 630 Author: FAO

Title of the FAO distribution and suplies / FAO

Publication

Subject No: 361.7706 Author: FAO

Title of the FAO programme for rehabilitation of Afghanistan agriculture

Publication $\mid$ : quarterly status reports

Subject No: $361.77 \mathrm{M}$ Author: Naimi, M. Qaseem

Title of the Fact finding mission to Nangarhar, July 8-9, $1992 /$ by

Publication M.gaseem Naimi

Subject No: 613 Author: UNICEF

Title of the Facts for life : a communication challange / UNICEF

Publication

Subject No: $630 \quad$ Author: SCA

Title of the Farm Poiver, volume / Swedish committee for Afghanistan

Pub. No: 66

Publication

Subject No: 630

Title of the Farm gross margin analysis of poppy growers in the five valleys

Publication of the Dir District / by A. Jameel siddiqi

Subject No: $630 \quad-$ Author: Eubanks, K. Scott

Title of the Farm machinary : 16 provinces in Afghanistan, Analysis and

Publication

recommendations / K. Scott Eubanks

Subject No: 630 Author: Hajid, Abdul

Title of the Farming systems of mountain areas

Publication

Subject No: 361.77M Author: Buddenburg, D.

Title of the Feasibility study for the establishment of a drug information

Publication

centre in Kabul, Afghanistan / D. Buddenburg

Subject No: 630 Author: SCA

Title of the Fertilizer / Swedish Committee for Afghanistan

Publication 
Subject No: 658.3 Author: Davies, D.J.

Title of the Field staff guide / Food and Agriculture organization of United

publication Nations

Subject No: 658.7 - Author: United Nations

Title of the Film library catalogue of the division of narcotic drugs / un

Publication

Subject No: 362.298 - Author: Sutphen, Trenna

Title of the Final cut, Instruction book and analysis questionnaires / Trenna

Publication sutphen

Subject No: 025.06 Author: Newton, John

Final report Afghanistan macroeconomic database development (tex)

Publication

/ John Newton, Harver lerner, Haris Jafri [et al.]

Subject No: 361.77M - Author: Buddenberg, D.

Title of the Final report on SSA (90-10759) to awareness creation compaign

Publication / D. Buddenburg

Subject No: 361.77M - Author: Buddenberg, Doris

Title of the Final report on consultancy to project AFP/89/580: Master

Publication framework for training Afghan women / D. Buddenberg

Subject No: 361.77M Author: Buddenberg, D.

Title of the Final report to awareness creation compaign / D. Buddenberg

Publication

Subject No: 363.45 Author: UsIs

\begin{tabular}{l|l} 
Title of the & Financial crimes and money laundering \\
Publication &
\end{tabular}

Publication

Subject No: 305.4 Author: Khan, Adalat

Title of the Financial facility for women development / Adalat Khan

Publication

Subject No: 338.1 - Author: Raditz, Cary W.

Title of the Financing cross-border trade : Reconstructing agriculture and

Publication agribusiness in Afghanistan / prepared by Cary W. Raditz

Subject No: 948.97 - Author: Costa, Da Riitta

Pub. No: 28

Title of the Find out about Finland/ editor Riitta Da costa

Publication

Subject No: 361.7706

Author: operation salam

Title of the First consolidated report september 1988 / UNOCA

Publication

Subject No: $\mathbf{6 3 0}$

Author: Gul, Azam

Title of the First report, May 1988 / Swedish Committee for Afghanistan

Publication

Subject No: $\mathbf{5 4 9}$

Author: Chamberlin-Bouversef, Bonita

Pub. No: 281

Pub. No: 350 
ACCESSION NO(s) FROM: 1 TO: 615

Subject No: 641.3 - Author: FAO - Pub. No: 471

Title of the Food outlook : Global information and Early Warning system on

Publication Food and Agriculture / FAO

Subject No: 005.1 Author: Fox Pro

Title of the Fox Pro, version 2.0: command and functions / Fox Pro

Publication

Subject No: 005.1 - Author:

Title of the Fox pro, version 2.0: Developer's guide

Publication

Subject No: 060

Title of the From aid during times of war to aid for reconstruction and

Author: Eide, Elizabeth

Publication development / edited by Elizabeth Eide and Terje slaufjord

- Pub. No: 310

Subject No: 664.024 Author:

Title of the Fruit and vegetable processing / UNIFEM

Publication

Subject No: 635

Author: Cartwright, Jim

Pub. No: 405

Title of the / Fruit programme / Jim Cartwright

Publication

Subject No: 362.29 Author: Cunningham, Donna

Title of the / Further dimensions of healing addictions / Donna Cunningham

- Pub. No: 407

Publication

Subject No: 305.4 Author: AL -Jalaly, S.zia

Title of the Gender issues and their implication for development in the north-

Publication

west frontier province / S.zia Al-Jalaly

Subject No: 362.29 - Author: Gay, Pat

Title of the Getting together : A study of self-help groups for drug users'

Publication families / Pat Gay

Subject No: 958.1 Author: UNRCR

Title of the Ghazni Province / prepared by the Data collection for Afghan

Publication

Repatriation Project

Subject No: 958.1 Author: UNIDATA

Title of the Ghazni Province, Afghanistan : A socio-economic profile

Publication / UNIDATA

Subject No: 615.1 - Author: Arterburn, stephen

Title of the Growing up addicted / stephen Arterburn

Publication

Subject No: $338.9 \quad$ Author: ACBAR

Title of the Guidelines for the planning and implementation of projects for

Publication agricultural rehabilitation in Afghanistan / ACBAR

Subject No: 362.29 Author: wHo

Title of the Guidlines for assessing alcohol and drug prevention programmes/

Publication wHo 
Subject No: 613

Title of the

Publication
Author: Mumtaz, A.z. (trans)

Pub. No: 397

Subject No: 614.4

Author: ACBAR

Title of the Health standards and guidelines / Health subcommittee, ACBAR

Publication

Subject No: $361.77 \mathrm{M}$

Author: Amaj, M. Rabi

Helmand projects monitor and supervision report, Jan 8-Feb 21,

Title of the

1991 / M. Rabi Amaj; translated by M. Saeed

Subject No: 630

Title of the

- Author: AASSP

Publication

Helmand-Arghandab valley irrigation system : A change assessment 1973-1990

Subject No: 362.292 Author: Children's Television Workshop (prepared Title of the Helping your child say no to alcohol / prepared by children's

Publication Television Workshop

Subject No: $371.1 \quad$ Author:

Title of the Helping your pre-team say "No" : a parents aid

Publication

Pub. No: 375

Subject No: 958.1

Author: UNHCR

Title of the

Herat Province / prepared by the Data collection for Afghan

Publication

Repatriation Project

Subject No: 362.293 Author: Platt, J.Jerome

Title of the Heroin addiction : Theory, reseach and treatment / Jerome J.Platt

Publication

Subject No: 362.293 - Author: Platt, Jerome $J$.

Title of the Heroin addiction : Theory, research and treatment / Jerome J.

Publication platt.

Subject No: 362.293 - Author: DAPRC

Title of the Heroin detofification in Pakistan / a study of treatment methods

Publication / DAPRC

\section{Subject No: 362.293 Author: PNCB}

Title of the Heroin detoxification : Guidelines for family doctors and

Publication primary health care workers / PNCB

Subject No: 615.1 Author: Chakravarty, Anima

Title of the Homeopathic drug personalities with therapeutic hints / by Anima

Publication Chakravarty

Subject No: Ref 025 - Author: Rolett, Virginia \& Kinney Jean (editors) - Pub. No: 1 Title of the How to start and run an alcohol and other drug information

Publication

centre : A guide / Editors Virginia Rolett, Jean Kinney

Subject No: 633.75 Author: ERIM

Title of the / Identification of poppy cultivation in Afghanistan / ERIM

Publication 
ACCESSION NO(s) FROM: 1 TO: 615

Subject No: 364.177 - Author: Alvarez, Elena H.

Title of the Illegal export-led growth in the Andes: A preliminary economic

Publication and socio-political assessment / by Elena H. Alvarez

Subject No: 364.177 - Author: Tullis, Lamond

Title of the Illicit drug taking prohibition laws : Public consequences $\&$ the

Publication reform of public policy in the United states

Subject No: 364.177 Author:

Title of the Illicit drugs in Pakistan and Afghanistan

Publication

Subject No: 630

Title of the

Publication
- Author: DAI / ASSP

Illustration of project impact on Afghanistan Agriculture 1989-1991/ ASSP

\section{Subject No: $635 \quad$ Author: Wakil, Abdul}

Title of the Importance of horticulture in Afghan agriculture / Abdul Wakil

Publication

Subject No: 635 Author: Schermerhorn, Richard W.

Title of the Improving fruit and vegetable marketing in developing countries

Publication / by Richard W. Schermerhorn

\section{Subject No: 362.29 Author: WHO}

Title of the Information manual on designe drugs / WHO

Publication

Subject No: 362.29 Author: WHO

Pub. No: 537

Title of the Inter - regional meeting on alcohol - related problems / who

Publication

Subject No: 323.64 Author: English, Richard

Title of the Interim reprot on repatriation planning for Afghan refugees/

Publication

Subject No: 363.45 Author: Usis

Title of the International Narcotics Control strategy Report : southwest Asia

Publication / UsIs

Subject No: $361.7706-$ Author: IRC

Pub. No: 234

Pub. No: 300

Title of the International Rescue Committee Program for Afghan : annual report

\begin{tabular}{l|l} 
Publication & $1989-/$ IRC
\end{tabular}

Subject No: 361.7706 - Author: International Rescue committee

Title of the International Rescue committee quarterly report / IRC

Publication

Subject No: 060

Author: PNCB

Title of the International conference of NGos for drug abuse prevention,

Publication Karachi August 20-25, 1988 / PNCB

Subject No: $060 \quad$ Author: PNCB

Title of the International conference on narcotics law enforcement,

Publication March 20-25, 1989 
ACCESSION NO(s) FROM: 1 TO: 615

Subject No: 060 Author: UNDND

Title of the International day against drug abuse and illicit trafficking

Publication / UN Division of Narcotics Drugs

Subject No: 363.45 Author: Bureau of Intertional Narcotics Matters

Title of the / International narcotics control strategy report / Bureau of

Publication International Narcotics Matters

Subject No: 361.7706 Author: INM

Title of the International narcotics control strategy report : Executive

Publication summary / INM

Subject No: $\mathbf{3 6 3 . 4 5}$ Author:

Title of the International narcotics control strategy report : Policy and

Publication programme overview for 1992 / UsIs

Subject No: 362.29 Author: United Nations

Title of the International strategy and policies for drug abuse / UN

Publication

Subject No: 363.45 Author: UNDND

Title of the International strategy and policies for drug control / Division

Publication of Narcotic Drugs

Subject No: 338.9 Author:

Pub. No: 354

Title of the Investment profiles for smaller industrial projects / centre for

Publication the Development of Industry

Subject No: 297 Author: Abedin, z.syed (ed)

Pub. No: 337

Title of the Journal : Institute of Muslim minorty affairs / editor syed z.

Publication Abedin

Subject No: 338.1 Author: Afghanaid

Title of the Kabul food survey, 15 May June 1989 / Afghanaid

Publication

Subject No: $\mathbf{3 6 3 . 8} \quad$ Author: Afghanaid

\begin{tabular}{l|l} 
Title of the & Kabul food survey, 15th May to 10th June 1989 / Afghanaid \\
publication &
\end{tabular}

Publication

Subject No: 958.1 - Author: UNHCR

Title of the / Kandahar Province / prepared by the Data collection for Afghan

Publication Repatriation Project

Subject No: 958.1 Author: UNIDATA

Title of the Kandahar Province, Afghanistan : a socio-economic profile

Publication / UNIDATA

Subject No: 362.29 Author: Corey, Anthony Michael

Title of the Kicking the drug habit : Acomprehensive self - help guide to

Pub. No: 494

Publication understanding the drug problem and overcoming addiction / Michael

Subject No: $958.1 \quad$ Author: UNHCR

Title of the Kunar Province / prepared by the Data collection for Afghan

Pub. No: 92

Publication Repatriation Project 
ACCESSION NO(s) FROM: 1 TO: 615

Subject No: 958.1 Author: UNHCR Pub. No: 93

Title of the Laghman Province / prepared by the Data collection for Afghan Publication Repatriation Project

Subject No: 364

- Author: PNCB

Title of the Law enforcement resource book on narcotics / PNCB Pub. No: 394

Publication

Subject No: 262.29 Author:

Title of the Learning factors in substance abuse / NIDA

Publication

Subject No: 362.2937 Author: Flatter, Charles H.

Title of the Learning to live drug free : A curriculum model for prevention

Publication / Charles H. Flatter and Kathleen McCormick, principal authors

Subject No: 371.1 Author:

Title of the Learning to live drug free : A curriculum model for prevention /

Publication us Department of education

Subject No: 362.299 Author: Coleman, Vernon

Title of the Life without tranquillisers / Vernon coleman

Publication

Pub. No: 117

Subject No: 060 Author: UNDP

Title of the List of personnel in Thailand, 1990 / UNDP

Publication

Subject No: 630 Author: SCA

Title of the / Liverstock / Swedish Committee for Afghanistan

Publication

Liverstock $f$ swedish Committee for Afghanistan

Pub. No: 2

Subject No: 362.293 Author: Parker, Howard

Title of the Living with heroin : The impact of drugs 'epidemic' on an English

Publication community / Howard Parker

Subject No: 958.1 Author: UNHCR

Title of the Logar Province / prepared by the Data collection for Afghan

Publication Repatriation Project

Subject No: 361.7706 Author: Madera

Pub. No: 283

Title of the Madera activity report

Publication

Subject No: 621.38418 Author: Magellan Systems Corporation

Title of the

Magellan GPS Nav 1000 Pro : User guide / Magellan Systems

Publication Corporation

Subject No: 0250Ref Author: Brown, Jeannie

Title of the Manual for managing a library, UNDCP / Jeannie Brown

Pub. No: 270

Publication

Subject No: 371.1 Author: UNFDAC

Title of the Manual for resource poisons and community workers in drug abuse

Publication prevention / UN Fund for Drug Abuse Control 
Subject No: 362.29 Author: UN Division of narcotic drugs Title of the / Manual on drug abuse assessment / UN Division of Narcotic Drugs

Publication

Subject No: 362.2937 Author: UNDND

Title of the Manual on drug abuse assessment : Part 2, Use of population

Publication surveys / UN Division of Narcotic Drugs

Subject No: 362.29 Author:

Pub. No: 374

Title of the Manual on drug abuse prevention education and community

Publication information for teachers, community leaders and workers, media

Subject No: $\mathbf{3 6 4}$

Title of the

- Author:

Pub. No: 395

Publication

Manual on the effective prevention and investigation of

extra-legal, arbitrary and summary executions / Unitet Nations

Subject No: 615.288 Author: Unitet Nations

Title of the Manufacture of narcotic drugs and psychotropic substances under

Publication international control / UN

Subject No: 630 Author: Kokab, Abrar A.

Title of the Marketing potatoes in Pakistan / Abrar A. Kokab and Alan E. Smith

Pub. No: 244

Publication

Subject No: 005.3 Author: siegal, Charles

Title of the Mastering Foxpro 2 / Charles siegal

Publication

Subject No: 613

- Author: WHO

Pub. No: 181

Title of the Masterplan for rehabilitation and reconstruction of the health

Publication system in Afghanistan / WHO

Subject No: $371.1 \quad$ Author: UNFDAC

Title of the Medical aspects of drug detoxification / prepared for un Fund for

Publication Drug Abuse control

Subject No: 362.29 - Author: Ashraf, Malik Mohammad

Title of the Menace of opiate abuse in Pakistan / by Malik Mohammad Ashraf

Pub. No: 29

Publication

Subject No: 364.177 - Author: Toro, Celia

Title of the Mexican drug control policy : origin, purpose, and consequences

Publication / Celia Toro

Subject No: 361.7706 Author: Operation Salam

Title of the Mine clearance Programme for Afghanistan : Mid year report, 30

Publication June 1993 / by Operation Salam

Subject No: 361.7706 Author: Operation Salam

Title of the Mine awareness programme progress report July 1 - september 30 ,

Publication 1990 / Operation Salam

Subject No: 361.7706 Author: Operation Salam

Title of the / Mine clearance programme for 1993 / by operation Salam

Publication 
Subject No: 361.77M - Author: Conrad, Christof H.

Title of the Mission to Kabul, Afghanistan 23 to 30 November 1989

/ Christof H. Conrad

Publication

Subject No: $361.77 \mathrm{M} \longrightarrow$ Author: Conrad, Christof $\mathbf{H}$.

Title of the Mission to Kabul, Afghanistan 23-30 November 1989 / Christof

Publication H. Conrad

Subject No: $361.77 \mathrm{M}$ Author: UNDCP

Title of the | Monitoring reports to Afghanistan / UNDCP

Publication

Pub. No: 341

Subject No: $361.77 \mathrm{M}$ Author: UNFDAC

Title of the Monitoring system for UNFDAC assisted cross - border operated

Publication projects / UNFDAC

Subject No: $361.77 \mathrm{M}$ Author: UNFDAC

Title of the Monitoring system for UNFDAC assisted cross - border operated

Publication projects / UNFDAC

Subject No: 615.1

Author: Miller, R.William, Ph.D.

Title of the Motivational enhancement therapy manual / William R.Miller, Ph.D.

Publication

Subject No: 630

Author: Sandhu, G.R.

Title of the / Mountain agricultural research system in Pakistan / by

Publication M. R. Sandhy

Subject No: 630 Author: Khattak, G.M.

Title of the Mountain agriculture in the development plans of NWFP / by

Publication G.M. Khattak

Subject No: 361.7706 Author: ACBAR

Title of the NGO's in Afghanistan : A brief overview / ACBAR

Publication

Subject No: 361.7706

Author: UNDP

Title of the NGO's working for others : Acontribution to human development

Publication

Subject No: 958.1 Author: UNHCR

Title of the Nangarhar Province / prepared by the Data collection for Afghan

Publication Repatriation Project

Subject No: 958.1 - Author: Shakir, (compiled by)

Title of the / Nangarhar provincial report / compiled by shakir

Publication

Subject No: 362.29 Author: International Narcotics Control Board

Title of the | Narcotic drugs : Estimated world requirements for 1989 /

Publication International Narcotics Control Board

Subject No: 362.29 Author: International Narcotics Control Board

Title of the Narcotic drugs : Estimated world requirements for 1992 ,

Publication statistics for $1990 /$ INCB 
ACCESSION NO(s) FROM: 1 TO: 615

Subject No: 362.293 - Author: ANPA

Title of the Narcotics and it's dangers / by Anti Narcotic Project for

Publication Afghanistan

Subject No: 362.293 - Author: ANPA

Title of the Narcotics and it's dangers / by Anti Narcotics Project for

Publication Afghanistan

Subject No: 361.77PD - Author: DAI

Title of the / Narcotics awareness and control project : Technical proposal /

Publication DAI

Subject No: 362.29207 Author: Lodi, Yusaf

Title of the Narcotics control through cartoons / Yusaf Lodi

Publication

Subject No: $362.293-$ Author: Sultana, zubida
Title of the / Narcotics materials make our youth live toxicated / zubida sultan

Pub. No: 590

Publication

Subject No: 633.75 Author: Schleiffer, Hedwig

Title of the Narcotics plants of the old world / Hedwig Schleiffer

Publication

Subject No: $060 \quad$ Author:

Title of the National Conference of NGos on drug abuse prevention / Green

Publication December Movement

Subject No: $630 \quad$ Author: Amir, Pervaiz

Title of the National conference on agricultural sustainability and natural

Publication resource management / Editors Pervaiz Amir, M. Yousaf Chaudhri,

Subject No: 362.29 Author: United Nations

Title of the National authorities empowered to issue certificates and

Publication authorizations for the import and export of narcotic drugs and

Subject No: 060 Author:

Title of the National directory of drug abuse and alcoholism : Treatment and

Publication prevention programs / U.S. Department of Health and Human

Subject No: 615.1 Author:

Title of the National drug reform strategy / The Drug Policy Foundation

Publication Nation

Subject No: 362.29 - Author: PNCB Publication

Subject No: 362.29 - Author: PNCB

Title of the National survey on drug abuse in Pakistan, 1986 / PNCB

Publication

Subject No: 362.29 Author:

Pub. No: 267

Title of the Needle sharing among intravenous drug abusers : National and

Publication international perspectives / NIDA 
ACCESSION NO(s) FROM: 1 TO: 615

Subject No: 362.29 Author:

Pub. No: 414

Title of the | Neurobiology of drug abuse : Learning and memory / NIDA

Publication

Subject No: $\mathbf{3 6 4 . 1 7 7}$

Author: Trebach, S.Arnold

Title of the New frontiers in drug policy/Arnold s.Trebach

Publication

Subject No: 305.4 Author: May, Nicky

Title of the No short cuts : A starter resource book for women's group field

Publication

workers / Nicky May \& the Networkers

Subject No: 630 Author: SCA

Title of the Northern Afghanistan : Crop protection programme / Swedish

Publication Committee of Afghanistan

Subject No: 630 Author: SCA

Title of the Northern Afghanistan : Food deficit survey / Swedish committee

Publication for Afghanistan

Subject No: 630 Author: SCA

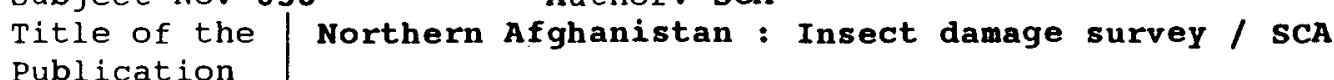

Publication

Pub. No: 166

Subject No: 361.77PD _ Author: UNDP

Title of the | Northern rural rehabilitation, Northern Afghanistan / UNDP

Publication

Subject No: $363.8 \quad$ Author: Afghanaid

Title of the Nutrition survey report, Badakhshan, Jowzjan and Faryab /

Publication [by Afghanaid Emergency Training Unit]

Subject No: 361.77PD Author: oPs

Title of the OPs user's guide : for ops-implemented projects / undP office for

Publication $\quad$ Project services

Subject No: 658.3 Author: oPs

Title of the / OPS user's guides for ops - implemented projects / OPS

Publication

Subject No: $658.7 \quad$ Author: oPs

Title of the OPS user's guides for oPs-implement projects : 3A Direct field

Publication procurement of equipment and supplies / ops

Pub. No: 167

Subject No: 001.4 Author: Schubert, Bernd

Title of the objectively verifiable indication - zOPP / Bernd schubert, Geert

Publication Balzer, Adelbert Engel

Subject No: 361.7706 Author:

Title of the office for Project sevices year end report 1991 / UNDP

Publication

Subject No: 664.024 Author:

Title of the oil extraction / UNIFEM

Pub. No: 476

publication 
Subject No: 633.85 - Author: Pakistan Agricultural Research Council Title of the oilseeds research and development in Pakistan : a perspective Publication / Pakistan agricultural Research council

Subject No: 630 Author: Devauf, A.

Title of the on - farm research activities in the plains of Pabbi, Peshawar

Publication District (NWFP), spring and autumn crops / A. Devauf, Ch.Javed

Subject No: 361.77PD - Author: Operation Salam

Title of the | Operation Salam 1990 document for Afghanistan / UNOCA

Publication

Subject No: 361.7706 Author: Operation Salam

\begin{tabular}{l|l} 
Title of the & Operation Salam programme for 1991 / by operation salam \\
Publication &
\end{tabular}

- Pub. No: 14

Pub. No: 286

Subject No: 361.7706 Author: Operation Salam

Title of the Operation Salam programme for 1991 : Progress report

Publication January - June 1991 / Operation Salam

Subject No: 361.7706 Author: Operation Salam

Title of the | Operation Salam progress report January - April 1990 / Operation

Publication salam.

Subject No: 361.7706 Author: Operation Salam

Title of the Operation Salam second consolidated report october 1989

Publication / Operation Salam

Subject No: 362.293 Author: Harding, Geoffrey

Title of the opiate addiction, morality and medicine, from moral illness to

Publication pathological disease / Geoffrey Harding

Subject No: 362.293 - Author: Simpson, D.Dwayne

Title of the Opioid addiction and treatment : A 12-year follow-up / Dwayne D.

Publication simpson

Subject No: 362.26 Author:

Pub. No: 272

Pub. No: 245

Title of the / opioid peptides : An update / National Institute on Drug Abuse

Publication

Subject No: 630

Author: Robert, G. Lamar

Pub. No: 12

Title of the opium crop replacement without tears or terror: The case of

Publication Northern Thailand 1971 - 1989 / G. Lamar Robert, Ronald D. Renard

Subject No: 633.75 Author: Brailsford, GuY

Title of the Opium crop substitution programme : Achin District, Nangahar

Publication

1989 / Guy Brailsford

Subject No: 633.75 Author: Hund, Anne E.

Title of the / opium poppy coltivation Nangarhar Province Afghanistan $1990 /$ by

Publication Anne E. Hund and Stephen J. Masty

Subject No: 633.75 - Author: Hurd, Anne E.

Title of the opium poppy cultivation Nangahar Province, Afghanistan / 1990 by

Publication Anne $E$. Hurd and Stephen I. Masty 
ACCESSION NO(s) FROM: 1 TO: 615

Subject No: 361.77M - Author: MacPherson, Nancy

Title of the Opportunities for improved environmental management in

Publication Afghanistan : Report of a mission / by Nancy MacPherson,

Subject No: 361.7706 Author: OMA

Title of the organization for mine awareness quarterly report 1991 - / office

Publication of Mine Awareness

Subject No: 361.7706 Author: OMAR Title of the Organization for mine clearance and Afghan Rehabilitation

Publication

Subject No: 325.21 Author: Breen, Rob

Title of the origins survey of refugees in NWFP / Rob Breen

Publication

Subject No: 361.7706 Author: Bennett, Jon

Title of the | Overview of NGo assistance : Afghan programmes 1990-1991/ Jon

Publication

Bennett, Mohammad Ismail Shakir, Marion couldrey, Nancy H. Dupree

Subject No: 413 Ref Author: Hornby, A.s.

Title of the | Oxford advanced learner,s dictionary of current English / A.s.

Publication Hornby; chief editor A.P. cource

Subject No: 362.29 Author: wHO

Pub. No: 539

Title of the / PSA's Approach to demand reduction / WHO

Publication

Subject No: 362.29 - Author: Haq, Ikramul

Pub. No: 63

Title of the Pakistan : From hash to heroin / by Ikramul Haq

Publication

Subject No: 262.2937 - Author: PNCB

Pub. No: 364

Title of the Pakistan fights narcotics menace / PNCB

Publication

Subject No: 361.7706 Author: PSPDP

Title of the Pakistan-Switzerland cooperative Project / PSPDP

Pub. No: 339

Publication

Subject No: 958.1 Author: UNHCR

Title of the Paktia Province / prepared by the Data collection for Afghan

Publication Repatriation Project

Subject No: 958.1 - Author: UNHCR

Title of the Paktika Province / prepared by the Data collection for Afghan

Publication Repatriation Project

Subject No: 362.2937 Author: OSAP's Division of Communications

Title of the Parent training is prevention : preventing alcohol and other drug

Publication problems among youth in the family / OSAP's Division of

Subject No: 307.72 Author: FAO

Title of the Participation in practice : Lessons from the FAo people's

Publication participation programme / FAO 
Subject No: 307.72 - Author: Ali Khan, Imdad

Title of the Participative management for rural development / Imdad Ali Khan, Publication Abdur Rashid, Abdul Aziz Awan

Subject No: 307.72 - Author: Feverstein, Marie-Therese

Title of the Partners in evaluation : Evaluating development and community

Publication programmes with participant / Marie-Therese Feverstein

Subject No: 615.1 Author: Rudman

Title of the Passbooks for career opportunities / Rudman

Publication

Pub. No: 443

Subject No: 362.29 Author: Donohew, Lewis

Title of the / Persuasive communication and drug abuse prevention / Lewis

Publication Donohew

Subject No: 630 Author: Rann, Jerry

Title of the Pilot Locust and senn pest control project for Afghanistan

Publication in Badghis Province / by Jerry Rann

Subject No: 362.2937 Author: Lusane, Clarence

Title of the Pip dream blues : Racism and the waron drugs / clarence Lusane

Publication

Pub. No: 485

Subject No: 305.4 Author: Beg, Ibrahim Mohammad

Pub. No: $\mathbf{5 4 5}$

Title of the Planning for women's integration in development situation

Publication analysis concerns, strategies and mechanism / Mohammad Ibrahim

Subject No: 363.45 Author: USIS

Title of the | Policy and program development in 1992 / by UsIs

Publication

Subject No: 633.75 Author: Owens, G.P.

Title of the Poppies in Afghanistan / by G.P. Owens and James H. Coifton

Pub. No: 578

Publication

Subject No: 362.293 Author: Westermeyer, Joseph

Title of the | Poppies, pipes and people: Opium and its use in Laos / Joseph

Publication westermeyer

Subject No: 633.75 Author: AIC

Title of the Poppy cultivation in Afghanistan

Publication

.75 Author: Cossee, olivier
Poppy cultivation in Afghanistan / olivier cossee

- Pub. No: $\mathbf{5 9 9}$

Title of the Poppy cultivation in Afghanistan / olivier cossee

Subject No: 362.29 Author: Walston, James

Pub. No: 256

Portrait of an industry where poison is a commodity / by James

Walston (pp. 35-41)

Subject No: 630 Author: Geddes, A.

Potato areas of Pakistan : Information on potato production by

agro-ecological zones / editors A. Geddes, A. Kokab

Pub. No: 248 

strategy for improvement and production, information / prepared

\section{Subject No: $362.5 \quad$ Author: World Bank}

Title of the Poverty reduction: Handbook and operational directive/

Publication

Subject No: 302.2 - Author: Haaland, Ane

Title of the Pretesting communication materials with special emphasis o child

Publication health and nutrition education: $A$ manual for trainers and

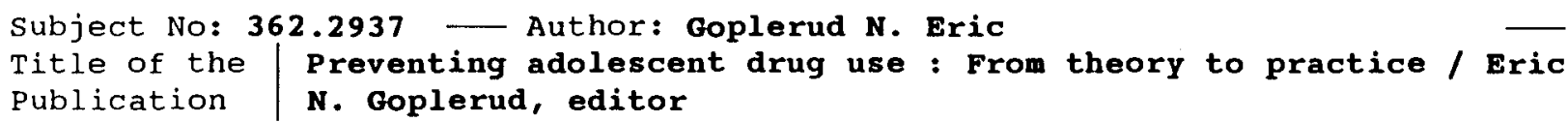

Subject No: 362.29 - Author: Gossop, M.

Title of the Preventing and controlling drug abuse / wHo

Publication

Subject No: 362.29 - Author: Frunkhouser, E.Judith A Amatetti Low

Title of the Prevention : From knowledge to action / prepared by Judith E.

Publication Funkhouser and Sharon Low Amatetti

Subject No: 362.2937 Author: OSAP

Title of the Prevention Plus II : Tools for creating and sustaining drug-free

Publication communities / OSAP

Subject No: 362.29 Author:

Title of the Prevention Research : Deterring drug abuse among children and

Publication adolescents / NIDA

Subject No: $362.29 \quad$ Author: WHO

Title of the | Prevention alcohol problems / wHo

Publication

Subject No: 362.29 - Author: Key, J.Addie

Title of the Prevention alcohol, Drug problems in inner - city communities :

Publication A model / Addie J.Key

Subject No: 362.29 Author:

Title of the Prevention and control of drug abuse $i$ Pakistan : First national

Publication workshop / Colombo Plan Burea

Subject No: 362.29 Author: Torjman, Sherri

Title of the Prevention in the drug field : a review of drug use/ written by

Publication sherri Torjman

Subject No: $630 \quad$ Author: Poulin, Roger

Title of the / Private sector Agribusiness support / prepared by Roger Poulin

Publication

Subject No: 060

Title of the Productions illicites et trafic de drogues : problematigues

Publication nationals et geopolitigues regionales / oGD 
Subject No: 362.29 - Author: WHO

Title of the Project on identification and management of alcohol - related

Publication problems / WHO

Subject No: $361.77 \mathrm{~m}$ Author: Buddenberg, D.

Title of the Project review mission, rural rehabilitation and reconstruction

Publication project, Afghanistan / Dr.D.Buddenberg

Subject No: 362.29 Author: Hussain, M

Pub. No: 367

Title of the Proposal for drug addiction treatment and pcychological

Publication rehabilitation centre / prepared by M. Hussain ; presented by

Subject No: 361.77PD Author: Anderson, Ian

Title of the | Proposal from RAFA for topographical survey of canal structures

Publication in Kunar

Subject No: $620 \quad$ Author: Arya, A.s.

Tit le of the Protection of educational buildings againest earthquakes /

Publication A.s. Arya

Subject No: 615.788 Author: International Narcotics Control Board

Title of the Psychotropic substances : statistics for 1987-/ INCB

Publication

Subject No: 613

Author: Ministry of Public Health

Pub. No: 459

Title of the Public health bulletin / Ministry of Public Health

Publication

Subject No: 307.72

Author: Cernea, Michael M., ed

Pub. No: 137

Title of the

Putting people first : Sociological variables in rural

Publication

development / edited by Michael M. Cernea

Subject No: 362.298 Author: Shaffer, J.Howard

Title of the Quitting cocaine : The struggle against impulse / Howard $J$.

Publication $\mid$ Shaffer, Ph.D.

Subject No: 361.7706 Author: CARE / WFP

Title of the Rebuilding Afghanistan with food for work / CARE - WFP

Publication

Subject No: $616.86 \quad$ Author: Galanter, Marc (ed)

Title of the Recent developments in alcoholism: vol. 8, Combined alcohol and

Publication

other drug dependence / Marc Galanter, editor

Subject No: 060

Title of the

Author: UNDP, UNFDAC

Pub. No: 391

Publication

Recommendations of the second UNDP / UNFDAC regional seminar on

replacement of opium poppy cultivation / UNDP, UNFDAC

Subject No: 630 Author: Camphell, Joseph

Title of the / Recommendations on farm machinery for use in Afghanistan /

Publication prepared by Joseph Camphell

Subject No: 614.1 - Author: UN Div. of Narcotic Drugs

Title of the Recommended methods for testing barbiturate derivatives under

Publication

international control : manual for use by national narcotics 
ACCESSION NO(S) FROM: 1 TO: 615

Subject No: 614.1 - Author: UN Div. of Narcotic Drugs

Title of the Recommended methods for testing peyote cactus (mescal buttons)

Publication / mescaline and psilocybe mushrooms / psilocubin / UN Div. of

Subject No: 362.29 Author: PNCB

Title of the Reflections on drug abuse / Pakistan Narcotics control Board

Publication

Pub. No: 376

Subject No: 362.29 Author:

Title of the / Reflections on drug abuse : NWFP report 1987 / Provincial

Publication Coordinator Health, NWFP

Subject No: $630 \quad$ Author: SCA

Title of the Regional Farming problems / Swedish Committee for Afghanistan

Publication

Subject No: 361.7706 Author:

Title of the Regional Remote Sensing Programme

Publication

Subject No: 958.1 - Author: UNIDATA

Title of the | Regional map of Afghanistan / UNIDATA

Publication

Subject No: 633.75 Author: UNDP

Title of the / Regional seminar in replacement of opium poppy cultivation / undp

Publication

Subject No: 658.3

- Author: United Nations

Title of the Regulations and rules of the United Nations Joint staff Pension

Publication $\quad$ Fund

Subject No: 658.3 - Author: United Nations

Title of the Regulations and rules of the United Nations joint staff Pension

Publication Fund / UN

Subject No: $361.77 \mathrm{M}$ Author: Stevens, E.John

Title of the Rehabilitation of agriculture in Afghanistan (seed, fertilizer

Publication and fruit tre component) / E.John, Mhd Morad, Abdul Wassi

Subject No: 361.77PD - Author: FAO

Title of the Rehabilitation of agriculture in Kunar Province of Afghanistan

Publication / FAO

Subject No: 361.77PD - Author: FAO

Title of the Rehabilitation of agriculture in selected central and south

Publication West afghan provinces (Paktika, Ghazni, zabol, and gandahar)

Subject No: $361.77 \mathrm{M}$ Author: Afghanaid

Title of the Rehabilitation programme in the Panjshir valley, monitoring trip,

Publication July-August $1989 /$ Afghanaid

Pub. No: 109

Pub. No: 169

Subject No: 621.3678 Author: Sader, steven A.

Title of the Remote sensing of narcotics: with special reference to

Publication techniques for detecting and monitoring of poppy production in

Pub. No: 134

Pub. No: 583 
Title of the Repatriation and rehabilitation survey Part $v$, western Paktia

Publication

Publication

Repatriation and rehabilitation survey part $I$, Khost area

Paktia / Swedish Committee for Afghanistan

Subject No: 630

- Author: SCA

Pub. No: 172

Title of the Repatriation and rehabilitation survey part II, Khogiani Area,

Publication Nangarhar / Swedish Committee for Afghanistan

Subject No: 630

Author: SCA

Pub. No: 345

Title of the

Repatriation and rehabilitation survey, Part III Kandahar / The

Publication Swedish Committee for Afghanistan

Subject No: 323.64 Author: UNHCR

Title of the | Repatriation of Afghan Refugees - 1992 / UNHCR

Publication

Subject No: 361.77PP - Author: Conrad, c.

Title of the Report mission to Kabul from 15 February to 6 March $1991 /$

Publication

C. Conrad

Subject No: 338.1 - Author: DAI

Title of the / Report of findings of bazaar survey IV / prepared by Development

Publication Alternatives, Inc

Subject No: 361.7706 Author: International Norcotics Control Board. Title of the | Report of the International Narcotics Control Board/INCB

Publication

Pub. No: 6

Subject No: 361.7706 Author: International Narcotics Control Board Pub. No: 479

Title of the | Report of the International narcotics control board for 1992 /

Publication INCB

Subject No: 633.75 - Author: Nathan-Berger

Title of the / Report of the opium subsector survey / Nathan - Berger

Publication

Afghanistan studies project

Subject No: 633.75 Author: AID

Title of the | Report of the opium substance survey / AID

Publication

Subject No: 371.1

Author: Ahmadi, Amir $\mathbf{M}$.

Title of the Report of the seminar for 40 teachers in Jalalabad. The capital

Publication of Nangarhar province in Afghanistan / Amir M. Ahmadi

Subject No: $361.77 \mathrm{M} \longrightarrow$ Author: Adam, Gerdox

Title of the Report on distance education in Afghanistan : mission to

Publication

Afghanistan and Pakistan 
Subject No: 338.1 - Author: Conner, Kerry M.

Title of the Report on findings of Bozaar survey I / Kerry M. Conner

Publication

Subject No: 338.1 - Author: DAI

Title of the Report on findings of bazaar survey II / prepared by Development

Publication Alternatives, Inc

Subject No: 621.2678 Author: Foederer, Michael

Title of the / Report on ground truthing missions to Afghanistan, April-May

Publication 1991 / prepared by Michael Foerderer

Subject No: $361.77 \mathrm{M} \longrightarrow$ Author: Buddenbery, Doris

Title of the Report on missions to Kabul, Afghanistan Doris Buddenderg

Publication

Subject No: 630

Author: Saari, Eugene E.

Title of the Report on wheat production in Afghanistan : an assessment of

Publication

potentials and problems / prepared by Eugene E. Saari

Subject No: 362.292 Author: Kozlowski, T.Lynn

Title of the Research advances in : Alcohol and drug problems / University

Publication of Toronto

Subject No: $362.29 \quad$ Author:

Title of the / Research findings on smoking of abused substances / National

Publication Institute on Drug Abuse

Subject No: 630

Title of the

Publication
Author: Highland Agriculture Project, Thailand

Research on economic and effective use of irrigation water for opium substitute crops in the Northern Thailand : Final report
Subject No: 630

Title of the

Publication
- Author: Highland Agriculture Project, Thailand.

Research on hydrological evaluation of land use factors related to water $y$ ields in the highlands as a basis for selecting
Subject No: 630

Title of the

Publication
Author: Highland Agriculture Project, Thailand Research on identification and production of diosgenin produced plants for opium poppy substitute in the highland of Northern
Subject No: $\mathbf{6 3 0}$ Title of the Publication
Author: Highland Agriculture Project, Thailand Research on industrial oil crops for opium substitution on the highlands of Northern Thailand : Final report / Highland
Subject No: 630 Title of the Publication
Author: Highland Agriculture Project, Thailand Research on small fruit production as substitute crops for opium poppy : final report / Highland Agriculture Project, Thailand

Subject No: 362.2937 Author: OSAP, ARF, Health \& Welfare Canada Pub. No: 413 Pub. No: 456 Pub. No: 188 - Pub. No: 237 
ACCESSION NO(s) FROM: 1 TO: 615

Subject No: 362.29 - Author: UNDND

Title of the Resource book of measures to reduce illicit demand for drugs Pub. No: 208 Publication

Subject No: 362.29 - Author: Grant, M.

Title of the Responding to drug and alcohol problems in the community/ wHo

Publication

Subject No: 630 Author: Freed, Denny

Title of the Restraints and possible interventions to increase agricutural

Publication inputs to and output from Afghanistan / prepared by Denny Freed

Subject No: $016 \quad$ Author: OSAP

Title of the Rural communities : Prevention Resource guide / osAP

Publication

Subject No: 361.77PD Author: UNFDAC

Pub. No: 550

Title of the Rural rehabilitation and reconstruction in Afghanistan / UNFDAC

Publication

Subject No: 361.7706 Author: UNDCP

Title of the Rural rehabilitation and reconstruction project activity and

Publication programme report June to December 1991 / UNDCP

Subject No: 613.81 - Author: Weisberg, Jeffrey

Title of the / Rx for recovery / Jeffrey Weisberg, M.D.

Publication

Subject No: 361.77M - Author: Operation Salam

Title of the Salam 3 mission report, 7 October - 19 November 1988 .

Publication / Jean-Jose Puig, Alfredo Witschi-Cestari, Michael

Subject No: 361.77M - Author: Operation Salam

Title of the Salam 6:400 Km through Paktika, 18-23 December $1988 /$

Publication operation salam

Subject No: 361.77M Author: Donini, Antonio

Title of the Salam mission to Randahar Province, 4 - 12 July 1989

Publication / Antonio Donini, Team leader

Pub. No: 220 
Subject No: 621.3678 Author: Etchegorry - Gastellu J.P.

Title of the / Satellite remote sensing for agricultural projects / J.P.

Publication Gastellu-Etchegorry, editor

Subject No: 362.29 Author:

Title of the Schools without drugs / us department of education

Publication

Subject No: 631.7 - Author: Roth, Alan D.

Pub. No: 252

Title of the Second evaluation of the Mae chaem watershed development project,

Publication Thailand / Alan D. Roth [et. al.]

\begin{tabular}{l|l} 
Subject No: 630 & Author: SCA \\
Title of the & Seeds / Swedish Committee for Afghanistan \\
Publication &
\end{tabular}

Subject No: $338.1 \quad$ Author: Pease, Andrew

Title of the seeds of plenty, seeds of want : social \& economic implication of

Publication the green revolution / by Andrew Pease

Subject No: 325.21 Author: Caritas

Title of the Seminar to exemine the Afghan refugees situation with a view to

Pub. No: 353

publication future Caritas development / Caritas

Subject No: 362.293 Author: Faupel, E.Charles

Title of the Shooting dope : Career patterns of hard-core heroin users /

Publication Charles E.Faupel

Subject No: 362.29 - Author: Millwood, David

Title of the / Smart promotion / David Millwood and Helena Gezelius

Publication

Subject No: 302.2 Huthor: Hunte, Pamela

Title of the Social communications and Afghans : continuity and change

Publication / Pamela Hunte

Subject No: 954.91 - Author: ziauddin (research by)

Title of the Socio - economic profile of Bajaur agency / research by ziauddin

Publication

Subject No: 364.177 - Author: Renard, Ronald D.

Pub. No: 114

Title of the Socio-economic and political impact of production, trade and use

Publication of narcotic drugs in Burma / Ronald D. Renard

Subject No: 363.45 - Author: USIS

Title of the Southeast Asia and the Pacific Austrailia .....

Publication

Subject No: 629.435 Author: Huk, ul Saif

Title of the / space research in Pakistan / suPARco

Publication

Pub. No: 469

Subject No: 001.4 Author: Agar, Michael H.

Title of the / Speaking of ethography / Michael H. Agar

Publication 
Subject No: 491.439 Author: Glassman, Eugene H.

Title of the | spoken Urdu : a beginning couise / Eugene H. Glassman

Publication

Subject No: 658.3 Author: United Nations

Pub. No: 135

Title of the / staff regulations / United Nations

Publication

Subject No: 361.7706 Author: ONCB

Title of the statistical report on narcotics control in Thailand $1984-1986$

Publication $/$ /ONCB

Subject No: 613.83 - Author: Hazelden

Title of the | staying clean : Living without drugs

Publication

Subject No: 362.29 Author: Hewett, c.Paul

Title of the / straght talk about drugs / Paul c.Hewett

Pub. No: 187

Publication

Subject No: $362.29 \quad$ Author: WHO

Pub. No: 508

Title of the / strategy document / WHO

Publication

Subject No: 362.29 - Author: wHO

Title of the

street children project : report of inaugural meeting of

participating centers / wHO

Publication

Subject No: $\mathbf{3 7 0}$

Author:

student's workbook / Mathematic grade II / second term

Publication

Subject No: 630

Title of the

Publication

Author: Bajwa, Khalid Ahmad

study of comparative advantage of turnips peas and potatoes in

Pub. No: 285

Kalam area / by Khalid Ahmad Bajwa, A.M.W Geddes

Subject No: 361.7706 Author: UNDP/OPS

Title of the

Publication sub-projects status report, 1 - 30 June / UNDP/OPs

Pub. No: 104

Subject No: 361.7706 Author: UNDP/OPS

Title of the | sub-projects status report, second quarter / UNDP/OPs

Pub. No: 501

Publication

Subject No: 361.77PD Author: UNDP

Title of the Publication

Subproject progress report January - March 1992 : Eastern Afghanistan Rural Rehabilitation / UNDP

Subject No: 362.29 Author: Berger, s.Louis

Title of the

Substance abuse as symptom : A psychoanalytic critique of

Publication

treatment appraoches and the cultural beliets that sustain them /

Subject No: 615.1 - Author: Nowinski, Joseph

Title of the

Substance abuse in adolescents and young adults: $A$ guide to

Publication

treatment / Josef Nowinski, Ph.D. 
Subject No: 361.7706 Author: Pakistan Red Crescent

Title of the

Publication Summary of welfare actvities 1989 / Pakistan Red Crescent

- Subject No: $\mathbf{3 3 8 . 1}$

Author: DAI

Pub. No: 240

Title of the

Publication

Survey III : a preliminary analysis of border catchment points

/ prepared by Development alternatives, Inc

- Subject No: 621.3678 - Author: The Remote Sensing Laboratory

Title of the Survey of narcotic plantation using spot data : remote

Publication sensing project / The Remote sensing Laboratory of the Asian

Subject No: 621.3678 Author: Galtier, Bertrand Pub. No: 139

Title of the Publication survey of the opium growing areas using spot imagery : Phase II, Final report / by Bertrand Galteir, pipop chamnivikaiping, Louis

Subject No: 362.293 Author: Gregorio, Di Antonio Title of the Survey of the opium growing areas, using remote sensing data,

Publication Technical report / Antonio $\mathrm{Di}$ Gregorio

Subject No: 630

Title of the

Author: Bajwa, Khalid Ahmad

Publication

Survival chances of old (desi) potato varieties in Gojal, Hunza

Valley / Khalid Ahmad Bajwa

Subject No: 362.29 - Author: Daley, Dennisc

Title of the Surviving addiction workbook / Dennis c.Daley

Publication

- Pub. No: 425

Subject No: 370 Author:

Title of the Teacher's handbook / Mathematic Grade II / first term

Publication

Subject No: 370

Author:

Title of the Teacher's handbook / Mathematic grade II / second term

Publication

Subject No: $\mathbf{3 7 0}$

Publication

Teacher's handbook / Mathematic grade II / third term

Subject No: $\mathbf{3 7 0}$

Author:

Title of the | Teacher's handbook / Mathematics grade I / first half

Publication

Subject No: $\mathbf{3 7 1}$ Author:

- Title of the / Teacher's handbook / Mathematics grade I / second half

Publication

Subject No: 370 Author:

Title of the / Teacher's handbook / Mathematics grade II / first term

Pub. No: 569

Publication

Subject No: $\mathbf{3 7 0}$

Publication

Teacher's handbook / Mathematics grade II / second term

Pub. No: 568 
AFG/89/580

LIST OF PUBLICATIONS IN ADCRP LIBRARY

ACCESSION NO(s) FROM: 1 TO: 615

Subject No: 370 Author:

Title of the Teacher's handbook / Pashto grade I / First term

Pub. No: 572

Publication

Subject No: 370 Author:

Title of the Teacher's handbook / Pashto grade I / Second term

Publication

Subject No: $\mathbf{3 7 0}$ Author:

Title of the Teacher's handbook / Pashto grade I / first half

Publication

Subject No: 370 Author:

Title of the Teacher's handbook / Pashto grade I / second half

Publication

Subject No: 370 Author:

Title of the / Teacher's handbook / Pashto grade II / first term

Publication

Subject No: $\mathbf{3 7 0}$ Author:

Title of the | Teacher's handbook / Pashto grade II / first term

Publication

Subject No: $\mathbf{3 7 0}$ Author:

Title of the Teacher's handbook / Pashto grade II / second tem

Publication

Subject No: $\mathbf{3 7 0}$ - Author:

Title of the Teacher's handbook / Pashto grade II / third term

Publication

Subject No: 370 Author:

Title of the Teacher's handbook / mathematic grade I / second term

Publication

Subject No: $370 \quad$ Author:

Title of the Teacher's handbook / mathematic grade I / first term

Publication

Subject No: 370 Author:

Title of the Teacher's handbook / mathematics grade II / third term

Publication

Subject No: 362.29 Author: PNCB

Title of the Teachers drug orientation resource book / Pakistan Narcotics

Publication control Board

Subject No: 371.1 Author: PNCB

Pub. No: 571 
-ACCESSION NO(s) FROM: 1 TO: 615

Subject No: 362.29 Author: Wyatt, John

Title of the Teaching about drugs / John Wyatt

Publication

Subject No: $371.1 \quad$ Author: UNFDAC

Title of the / Teaching about drugs : Instruction manual / prepared for UN Fund

Publication for Drug Abuse Control

-Subject No: 362.2937 - Author: Flynn, stephen P.

Title of the Teaching about substance abuse: A resource manual for faculty

publication development / stephen P. Flynn, Ardis K. Davis,

Subject No: $371.1 \quad$ Author: Flynn, P.Stephen

Title of the Teaching about substance abuse : A resource manual for faculty

Publication development / stephen P.Flynn

Subject No: $371.1 \quad$ Author: DEA

Title of the Team up for drug prevention with America's young athletes/

Publication Forest Hills school District

Subject No: 060 Author: UNDCP

Title of the Technical consultation on drug issues in southvest Asia,

Publication september 21-23, 1992 / collated by UNDCP

Subject No: 363.45 Author: UNDCP

Title of the Technical consultation on drug issues in southwest Asia / UNDCP

Pub. No: 461

Publication

Subject No: 361.7706 Author: Office of the Narcotic Control Board

Title of the Thailand Narcotics annual report, 1990 / office of the Narcotics

Publication control Board

Subject No: 615.58 - Author: Cocores, James

Title of the The 800 - cocaine : Book of drug and alcohol recovery / James

publication cocores M.D.

Subject No: 362.29 Author: Mcclure, Rowland Cynthia

Pub. No: 372

Title of the The courage to go on / Cynthia Rowland McCure

publication

Subject No: $\mathbf{3 2 0}$

Author: IRS

Title of the The Indo-Lankar accord: An assessment / IRS

publication

Subject No: 305.908 - Author: Morton, John

Pub. No: 243

Title of the The socio - economic status of Afghan refugees in Pakistan : an

Publication

overview / John Morton

Subject No: $362.29 \quad$ Author: United Nations

Title of the The United Nations Fund for Drug Abuse control

Pub. No: 70

Publication

Subject No: 362.298 Author: Koskinen, Vrjo Eero (ed)

Pub. No: 455

Title of the

The United Nations Insternational Drug Control Programme in

Publication

Bolivia 1985-1992 : 2000 days against drugs / Eero 
ACCESSION NO(s) FROM: 1 TO: 615

Subject No: 362.29 Author: United Nations

Title of the The United Nations and drug abuse control / UN

Publication

Title of the The United Nations and drug abuse control / UN

Publication

Subject No: 362.29 Author: Fort, Joel

Title of the The addicted society : Pleasure - seeking and punishment

Publication revisited / Joel Fort

Subject No: 413

Title of the

Publication
- Author: Fay, J.John

The alcohol / drug abuse dictionary and encyclopedia / John J.Fay

Subject No: 345.0242 - Author: The Drug Policy Foundation

Title of the The andean strategy reconsidered:Toward a sensible international

Publication drug policy / The Drug Policy Foundation

Subject No: 363.45 - Author: Cooper, Mary $\mathbf{H}$.

Title of the The business of drugs / Mary H. Cooper

Publication

Subject No: 305.4 Author:

Title of the The changing role of woman with special emphasis on their

Publication economic role : country report of Indonesia / office of the

Subject No: 658.7 Author: EPI - WHO

Title of the The coldchain product information sheets / EPI, WHO

Publication

Subject No: 362.293 Author: Platt, J.Jerome - Kaplan, D.Charles\&

Pub. No: 33

Title of the

Publication

The effectiveness of drug abuse treatment : Dutch and American

perspectives / edited by Jerome J. Platt, Charles D. Kaplan,

Subject No: 362.29 - Author: UNDCP - ACC

Title of the

The extent of knowledge of drugs and drug abuse in Nasir Bagh,

Publication

Gandaf and Baraki refugee camps in NWFP Pakistan / UNDCP-ACC

Subject No: 15.788 Author: stimmel, Barry

Title of the

The facts about drug use : coping with drugs and alcohol in your

Publication

family, at work, in your community / Barry stimmel, M.D.

Subject No: 354.177 Author: Trebach, S.Arnold

Title of the The great issues of drug policy / Arnold s.Trebach

Publication

Subject No: 362.29 Author: Rogers, I.Ronald

Pub. No: 454

Pub. No: 140

Pub. No: 487 
-ACCESSION NO(s) FROM: 1 TO: 615

Subject No: 362.29 - Author: Peel, stanton

Title of the The meaning of addiction : Compulsive experience its interpretion

Publication / stanton Peele

Subject No: 362.293 - Author: Pearson, Geoffrey

Pub. No: 115

Title of the The new heroin users / Geoffrey Pearson

Publication

-Subject No: 361.3 Author: NAC

Title of the The other side of the border : An introduction to relief work

Publication inside Afghanistan / Norwegion Afghanistan Committee

- Subject No: 364.177 Author: Thoumi, Francisco E.

Title of the | The political economy of Columbia and the growth of the illegal

Publication psychoactive drugs industry / Francisco $E$. Thoumi

Subject No: 630 Author: Timmer, c. Peter

Title of the The role of agriculture in employment generation and economic

Publication distribution in Asia an the Near East / c.Peter Timmer

Subject No: 362.1 Author: Grant, P.James

Title of the The state of the world's children 1994 / James P.Grant

Publication

Subject No: 362.7 - Author: UNICEF

Title of the The state of the world's children, 1990 / UNICEF

Publication

Subject No: 362.293 - Author: stephens, C. Richard

Title of the The street addict role : A theory of heroin addiction / Richard

Publication c.stephens

Subject No: 600

Author: Sandhu, Ruby \& Sandler Joanne (compileted.

Pub. No: 613

Title of the The tech and tools book : A guide to technologies women are using

-Publication worldwide / compiled by Ruby Sandhu and Joanne Sandler

Subject No: 615.1 - Author: Yablonsky, Lewis

Title of the The therapeutic community : A successful approach for treating

Publication substance abusers / Lewis Yablonsky, Ph.D.

Subject No: 958.1 Author: D'Souza, Frances

Title of the The threat of famine in Afghanistan : a report on current

Publication economic and nutritional conditions / Fraces D'Souza

Subject No: 363.45 Author: Ghosh, S.K.

-Title of the The traffic in narcotics and drug addiction / s.K. Ghosh

Publication

Subject No: 362.2937 Author: Alcohol and Drug Foundation Pub. No: 77

ub. No: 482 
ACCESSION NO(S) FROM: 1 TO: 615

Subject No: 362.299 - Author: Morton, Ian K.M.

Title of the Tranquillizers : The comprehensive guide / Ian K.M. Morton, John

Publication Halliday, Judith M. Hall

Subject No: 307.72 - Author: Mickelwait, Donald R.

Pub. No: 293

Title of the Tribal areas development project, Pakistan : second evaluation

Fublication / Donald R. Mickelwait, Richard English, Jonathan Greenham,

- Subject No: 364.177 - Author: Fehim, Teoman (ed)

Publication Teoman Fehim, editor-in-chief

Subject No: 615.1 - Author: Nowinski, Josef

Pub. No: 439

Title of the Twelve step facilitation therapy manual / Josef Nowinski, Ph.D.

Publication

Subject No: $069.52 \quad$ Author: UNDP

Title of the U.s. System, Field motor cycles / UNDP

Pub. No: 463

Publication

Subject No: 069.52 Author: UNDP

Title of the UN system : Field motor vehicles / by Inter - Agency Procurement

Publication Services office

Subject No: 361.77 Author: UNDCP

Title of the UN plan of action for Afghanistan 1992 / UNDCP

Publication

Subject No: 350.15 Author: Craggs, Dennis

Pub. No: 458

Title of the UNDCP consultancy report, drug control and rehabilitation /

Publication Dennis Craggs

Subject No: 361.77 pd Author: UNDCP

Title of the UNDCP project document - standard format and guidines

Publication

Subject No: $060 \quad$ Author: UNHCR

Title of the UNHCR EDP Deregistration database

Publication

Subject No: 361.7706 Author: UNICEF

Title of the UNICEF Annual Report 1993

Pub. No: 606

Publication

Subject No: $361.77 \mathrm{M} \longrightarrow$ Author: UNV

Pub. No: 605

Title of the

UNV and Afghanistan : Evaluation and mission report 1991 /

Publication

Wiston R. Prattey, Frank O'Donnell

Subject No: 363.45 Author: UsIs

Title of the Usis report : Canada, Mexico, Central America

Publication

Subject No: 363.45 Author: UsIs

Pub. No: 467

Title of the Usis report : Us drug policy

Publication 
ACCESSION NO(S) FROM: 1 TO: 615

Subject No: 628.13 Author: Ritter, Charles M.

Title of the Understanding potable water storage / by Charles M. Ritter

Publication

Subject No: 658.7 Author: United Nations

Title of the United Nations Children's Fund supply division procurement and

Publication assembly centre : catalogue / UN

Subject No: 633.75M Author: Weir, Andrew

Title of the United Nations International Drug Control Programme :

Publication Consultant's report / Andrew Weir

Subject No: $361.77 \mathrm{M}$ Author: United Nations

Title of the United Nations office for Rehabilitation strategy for

Publication Afghanistan : Agricultural Sector

Author: United Nations Drug Control Programme

Title of the

United Nations drug law enforcement training manual : a guide for

Publication

law enforcement officials / UN Drug Control Programme

Subject No: $635 \quad$ Author: Parsons, David B.

Title of the Vegetable program / prepared by David B. Parsons

Publication

Subject No: 630

Author: The World Bank

Title of the Vetiver grass : The hedge against erosion / The World Bank

Publication

Subject No: 600

Author:

Title of the village technology handbook / Volunteers on Technical assistance

Publication

Subject No: 613

Title of the Vital statistics collection in Afghanistan a pilot study / by

Publication Faizullah Kakar

Subject No: 630

Author: Smith, Leighton

Title of the Viticulture : Raisin programme prepared by / Leighton

Publication

Subject No: 362.29 Author: wHO

Title of the | wHo initiative on cocaine : Meeting of project advisers / wHo

Publication

Subject No: 364.177 - Author: Mauj, M.

Title of the | War : The main factor of spreading cultivation of narcotic plants

Publication

in Afghanistan / M. Mauj

Subject No: 958.1 Author: UNHCR

Title of the

Wardak Province / preapared by the Data collection for Afghan

Repatriation Project

Publication

Subject No: $958.1 \quad$ Author: UNIDATA

Pub. No: 608

Pub. No: 190

Pub. No: 543

Title of the | Wardak Province, Afghanistan : A socio-economic profile / UNIDATA

Publication 
ACCESSION NO(s) FROM: 1 TO: 615

Subject No: 364.177 - Author: Posner, L.Gerald

Title of the | Warlord of crime : Chinese secret societies : The new mafia /

Publication Gerald L.Posner

Subject No: $910.3 \quad$ Author:

Title of the Washington, DC and vicinity : Index to map sheets

Publication

- Subject No: 630

Title of the

Publication

Author: Highland Agriculture Project, Thailand

Pub. No: 40

weed control research on upland rice and potatoes to replace opium based agriculture : Final report / Highland Agriculture

Subject No: 362.29

Author: osAP

Title of the What you can do about drug use in America / osAP

Publication

Subject No: 153.35 - Author: Leonard, Linda Schierse

Title of the | Witness to the fire : Greativirty and the veil of addiction/

Publication

Linda Schierse Leonard

Subject No: 362.293 Author: Rosenbaum, marsha

Pub. No: 427

Title of the Woman on heroin / Marsha Rosenbaum

Publication

Subject No: 615.1 - Author: Greenleaf, vicki D.

Pub. No: 422

Title of the Women and cocaine / Vicki D. Greenleaf

Publication

Subject No: 305.4 - Author: Utas, Bo (ed)

Pub. No: 120

Title of the Women in Islamic societies : Social attitude and historical

Publication perspectives / edited by Bo Utas

Subject No: 362.29 Author: wHo

Title of the Work plan 1993 / WHO

Publication

Subject No: 621.3678 - Author: ESCAP / RRSP

Title of the Working papers : Meeting of the directors of the National Remote

Publication sensing Centers / Programmes in the Escap Region and 9th session

Subject No: $958.1 \quad$ Author: UNHCR

Title of the Zabul Province / prepared by the Data collection for Afghan

Publication

Repatriation Project

Subject No: $370 \quad$ Author:

- Title of the teacher's handbook / Pashto grade II / second term

Publication

Subject No: 370 Author:

\begin{tabular}{l|l} 
Title of the & teacher's handbook / Pashto grade II / third term \\
Publication &
\end{tabular}

Publication

Pub. No: 610

Pub. No: 145

Pub. No: 565 
Subject No: 362.29 - Author: Harrison-Burns, Bettye

Title of the A guide to multicultural drug abuse prevention

Publication

Subject No: $361.7706-$ Author: ADA

Title of the Afghan development association

Publication

Pub. No: 473

L Subject No: 362.0425 Author: UNDCP

Title of the Afghanistan rehabilitation strategy : social services / UNDP

Publication Kabul Afghanistan

Subject No: 362.0425 Author: UNDCP

Title of the / Afghanistan rehabilitation strategy : executive summary / UNDCP

Publication Kabul - Afghanistan

Subject No: 362.29 Author: Erikson, Are

Title of the Alcohol and drugs : Perspectives, prevention and control -

Publication Asia Pacific region / edited by Are Erikson, Dayala Abeysekera,

\author{
Subject No: 613 \\ Author: Williams, Glen \\ Title of the All fo health : a resource book for Facts for life \\ Publication \\ Pub. No: 329
}

Subject No: 305.908 Author: Operation Salam

Title of the Committee on assistance to disabled Afghans : Guidelines and

Publication priorties / Operation Salam

Pub. No: $\mathbf{5 2 2}$

Subject No: 362.2937 Author: Arkin, Bralic Elaine \& Funkouser, E.
Title of the
Publication

Subject No: 362.2937 Author:

Title of the Communications manual for drug abuse prevention programs

Publication / Asia Near East Regional Norcotics Education Program

Subject No: 371.1 _ Author: PNCB

Title of the Community intervention against heroin abuse : Trainers manual

Publication / PNCB

Subject No: 362.2937 Author:

Title of the Community organization guide : A framework for community

Publication

involvement in drug abuse prevention / Division of substance

Subject No: 362.29 Author: Garrison, Thresa Pub. No: 383

Title of the Do it with skits : a guide to presenting your prevention program

Publication / Theresa Gassison

Subject No: 362.2937 Author: Walsh, Peter

Pub. No: 312

\begin{tabular}{l|l} 
Title of the & Drug education - a personal development issue : a guide for \\
Publication & victorian teachers / Peter Walsh, Ruth Freedman, Geoff Munro
\end{tabular}

Subject No: 370 Author: UNEsco

Title of the Educating against drug abuse

Publication 
$\mathrm{AFG} / 89 / 580$

LIST OF PUBLICATIONS IN ADCRP LIBRARY

- SUBJECT = EDUCATION

Subject No: 370 Author: UNESCO

Title of the

Publication

Education for all

Subject No: 370 Author: UNESCO

Title of the Education for all

Publication

Subject No: 613

Author: UNICEF

Title of the Facts for life : a communication challange / UNICEF

Publication

Subject No: $361.77 \mathrm{M} \longrightarrow$ Author: Buddenberg, D.

Title of the Final report to awareness creation compaign / D. Buddenberg

Publication

Subject No: 362.29 Author: Gay, Pat

Title of the Getting together : A study of self-help groups for drug users'

Publication families / Pat Gay

Subject No: 613 Author: Mumtaz, A.z. (trans)

- Pub. No: 397

Title of the Health education / z.A. Mumtaz, translator

Publication

Subject No: $371.1 \quad$ Author:

Title of the Helping your pre-team say "No" : a parents aid

Publication

Subject No: 060

Title of the International conference of NGos for drug abuse prevention,

Publication Karachi August 20-25, 198B / PNCB

Subject No: 362.2937 Author: Flatter, Charles H.

Title of the Learning to live drug free : A curriculum model for prevention

Publication / Charles H. Flatter and Kathleen McCormick, principal authors

Subject No: 362.29 Author:

- Pub. No: 374

Title of the Manual on drug abuse prevention education and community

Publication information for teachers, community leaders and workers, media

Subject No: $361.77 \mathrm{M}$ - Author: Conrad, Christof $\mathrm{H}$.

Title of the Mission to Kabul, Afghanistan 23 to 30 November 1989

Publication

/ Christof H. Conrad

Subject No: 362.29 Author:

Pub. No: 281

Pub. No: 313

Pub. No: 119

Title of the Needle sharing among intravenous drug abusers : National and

Publication

international perspectives / NIDA

Subject No: 362.2937 - Author: OSAP's Division of Communications

Pub. No: 375

Title of the

Parent

problems among youth in the family / OSAP's Division of

publication

Subject No: 302.2 Author: Haaland, Ane

Title of the Pretesting communication materials with special emphasis o child

Publication

health and nutrition education : A manual for trainers and 
SUBJECT = EDUCATION

Subject No: $362.2937-$ Author: Goplerud N. Eric

Title of the Preventing adolescent drug use : From theory to practice / Eric

Publication N. Goplerud, editor

Subject No: 362.29 - Author: Frunkhouser, E.Judith \& Amatetti Low

Title of the | Prevention : From knowledge to action / prepared by Judith E.

Publication Funkhouser and Sharon Low Amatetti

Subject No: 362.2937 Author: OSAP

Title of the Prevention Plus II : Tools for creating and sustaining drug-free

Publication communities / OSAP

Subject No: 362.29 Author: PNCB

Title of the Reflections on drug abuse / Pakistan Narcotics control Board

Publication Reflections or

Subject No: 362.29 Author:

Title of the Reflections on drug abuse : NWFP report 1987 / Provincial

Publication Coordinator Health, NWFP

Subject No: $371.1 \quad$ Author: Ahmadi, Amir M.

Title of the Report of the seminar for 40 teachers in Jalalabad. The capital

Publication of Nangarhar province in Afghanistan / Amir M. Ahmadi

Subject No: $361.77 \mathrm{M}$ - Author: Adam, Gerdox

Title of the Report on distance education in Afghanistan : mission to

Publication Afghanistan and Pakistan

Subject No: $361.77 \mathrm{PD}$ Author: UNFDAC

Title of the | Rural rehabilitation and reconstruction in Afghanistan / UNFDAC

Publication

Subject No: 954.91 - Author: Ziauddin (research by)

Title of the Socio - economic profile of Bajaur agency / research by ziaudin

Publication

Subject No: $370 \quad$ Author:

Title of the student's workbook / Mathematic grade II / second term

Publication

Subject No: $\mathbf{3 7 0}$

Author:

\begin{tabular}{l|l} 
Title of the & Teacher's handbook / Mathematic Grade II / first term \\
Publication
\end{tabular}

Publication

Pub. No: 338

Subject No: $370 \quad$ Author:

Title of the Teacher's handbook / Mathematic grade II / second term

Publication

Subject No: $\mathbf{3 7 0}$ Author:

Title of the Teacher's handbook / Mathematic grade II / third term

Publication

Subject No: $\mathbf{3 7 0}$ Author:

Title of the Teacher's handbook / Mathematics grade I / first half

- Pub. No: 574

Publication 
AFG $/ 89 / 580$

LIST OF PUBLICATIONS IN ADCRP LIBRARY

- SUBJECT = EDUCATION

Subject No: 371 Author:

Title of the Teacher's handbook / Mathematics grade I / second half publication

Subject No: $\mathbf{3 7 0}$

Author:

Title of the Teacher's handbook / Mathematics grade II / first term

Publication

- Subject No: $\mathbf{3 7 0}$

Author:

Title of the | Teacher's handbook / Mathematics grade II / second term

Publication

- Subject No: $\mathbf{3 7 0}$

Author:

\begin{tabular}{l|l} 
Title of the & Teacher's handbook / Pashto grade I / First term \\
Publication &
\end{tabular}

Publication

Pub. No: 572

Subject No: 370 Author:

Title of the Teacher's handbook / Pashto grade I / second term

publication

- Subject No: 370 Author:

Title of the Teacher's handbook / Pashto grade I / first half

Publication

subject No: 370

Title of the Teacher's handbook / Pashto grade I / second half

Publication

Author:

Subject No: $\mathbf{3 7 0}$

\begin{tabular}{l|l} 
Title of the & Teacher's handbook / Pashto grade II / first term \\
Publication &
\end{tabular}

Publication

Subject No: $\mathbf{3 7 0}$ Author:

Title of the Teacher's handbook / Pashto grade II / first term

Publication

Subject No: $\mathbf{3 7 0}$ Author:

Title of the Teacher's handbook / Pashto grade II / second tem

Publication

Author:

Subject No: 370

Title of the | Teacher's handbook / Pashto grade II / third term

Subject No: $\mathbf{3 7 0}$

Author:

Title of the Teacher's handbook / mathematic grade I / second term

Publication

Subject No: 370 Author:

- Title of the Teacher's handbook / mathematic grade I / first term Publication

Subject No: $\mathbf{3 7 0}$

Author:

- Title of the | Teacher's handbook / mathematics grade II / third term Publication

Pub. No: 558

Pub. No: 561

Pub. No: 564

Pub. No: 563

Pub. No: 562

Pub. No: 573

Pub. No: $\mathbf{5 7 0}$

Produced on 30/01/94 at 15:11:37

Page: 4 
- SUBJECT = EDUCATION

Subject No: 362.29 - Author: PNCB Pub. No: 198 Title of the Publication Teachers drug orientation resource book / Pakistan Narcotics control Board

Subject No: 371.1

Author: PNCB

Pub. No: 242

Title of the

Publication

Teachers drug orientation resource book / Pakistan Narcotics control Board

Subject No: 362.29 Author: PNCB

Title of the Teachers' guide to drug abuse prevention / PNCB

Publication

- Subject No: 362.2937

Author: Flynn, stephen P:

Title of the Teaching about substance abuse : A resource manual for faculty

Publication development / stephen P. Flynn, Ardis K. Davis

Subject No: 362.29

Author: OSAP

Title of the | what you can do about drug use in America / osAP

Pub. No: 311

Publication

Subject No: $\mathbf{3 7 0}$

Author:

Title of the teacher's handbook / Pashto grade II / second term

Publication

Subject No: $\mathbf{3 7 0}$

Title of the teacher's handbook / Pashto grade II / third term

Publication 
Title of the

Publication

Subject No: $\mathbf{6 5 1 . 1}$

Author: Finnegan, John

Title of the

Publication

Addictions : A nutritional approach to recovery / John Finnegan

Subject No: $\mathbf{6 1 5 . 1}$

Author: Fleming, Michael F.

Pub. No: 429

Title of the

Publication

Addictive disorders / Michael F.Fleming

Subject No: 362.0425 Author: UNDP

Title of the

Afghanistan rehabilitation strategy : National context / UNDP

Publication Kabul Afghanistan

Pub. No: 518

- Subject No: 362.292 - Author: Cook, Paddy Shannon

Title of the

Publication

Alcohol, tobacco, and other drugs may harm the unborn / Paddy Shannon Cook

Subject No: 362.29 Author: Sherman, Pecki

Title of the

Publication

Broken heart whole heart, afamily addiction / Pecki sherman

Pub. No: 423

Subject No: 363.45 Author: UsIS

Title of the | chemical controls / by usis

Publication

Pub. No: 579

Subject No: 362.29 - Author: Kinney, Jean

Title of the | clinical Manual of substance abuse / Jean Kinney, MSW

Publication

Clinical Manual of substance abuse $/$ Jean Kinney, MsW

Pub. No: 436

Subject No: 615.1 Author:

Title of the Cognitive - behavioral coping skill therapy manual

Publication

Subject No: 345.0242 Author: Shulging, T.Alexander

Title of the controlled substances: Chemical and legal guid to federal drug

Publication laws / Alexandar T.Shulging, Ph.D.

Subject No: 413 - Author: Kumar, Raj \& Anand Satish (editors)

Title of the | Dictionary of drugs / edited by Raj Kumar and Satish Anand

Publication

Subject No: $\mathbf{4 1 3}$

Pub. No: 65

Title of the Digestive drugs / Douglas M. Borland

Publication

Subject No: $\mathbf{6 1 6 . 8 9 1 8 ~ - ~ A u t h o r : ~ H u b b a r d , ~ L . R o b e r t ~}$

Title of the

Drug abuse

Publication

I. Rubbard

Subject No: 615.78 - Author: Brady, C.John

Drug addicts : Are they out of control ?/John C.Brady

Publication

Pub. No: 453

Robert

Pub. No: 64 
SUBJECT $=$ DRUGS

Subject No: 362.29 Author: Zaheer Khan, M.

- Title of the / Drug dependence in Pakistan / M. Zaheer Khan

Publication

Subject No: 362.29 Author: Royal College of Psychiatrists

Title of the / Drug scenes : a report on drugs and drug dependence / by The

Publication Royal college of Psychiatrists

Subject No: 615.1 - Author:

Title of the Drug use and misuse : A reader / Open University Milton Keynes

Pub. No: 435

Publication

- Subject No: 362.2917 Author: Carroll, R.Charles Title of the Drugs : In modern society / Charles R.Carroll

Publication

- Subject No: 363.45 Author: Kelleher, Maureen E. Title of the Drugs and society : A critical reader / Maureen E.Kelleher Publication

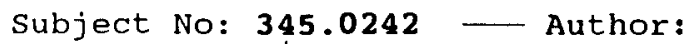

Title of the Drugs, crime, and the Justice system / Bureau of Justice Publication statistics

Subject No: 362.29 Author: Rucker, R.D.

Title of the | Drugs, drug addiction and drug dealing / R.D.Rucker

Pub. No: 82

Publication

Subject No: 614.4

- Author: National Institute on Drug Abuse

Title of the Epidemiologic trends in drug abuse / National Institute on Drug

Publication Abuse

Subject No: 615.1 Author: Chauhan, R.K.

Title of the Expressive drug pictures of materia medica Part 2 / by R.K.

Publication Chauhan

Subject No: 615.1 - Author: Arterburn, Stephen

Title of the Growing up addicted / stephen Arterburn

Publication

Subject No: 615.1 - Author: Chakravarty, Anima

Title of the Homeopathic drug personalities with therapeutic hints / by Anima

- Publication chakravarty

Subject No: 362.29 Author: Corey, Anthony Michael

Title of the Kicking the drug habit : Acomprehensive self - help guide to

Pub. No: 494

Publication understanding the drug problem and overcoming addiction / Michael

Subject No: $\mathbf{3 7 1 . 1}$

Author:

Title of the / Learning to live drug free : A curriculum model for prevention /

Publication us Department of education

Subject No: 362.299 - Author: Coleman, Vernon

Title of the Life without tranquillisers / Vernon coleman

Publication 
- SUBJECT $=$ DRUGS

Subject No: 615.288 Author: Unitet Nations - Pub. No: 186

- Title of the Manufacture of narcotic drugs and psychotropic substances under

Publication international control / UN

Subject No: 362.29 Author: United Nations

Title of the National authorities empowered to issue certificates and

Publication authorizations for the import and export of narcotic drugs and

- Subject No: 615.1 Author:

\begin{tabular}{l|l} 
Title of the & National drug reform strategy / The Drug Policy Foundation \\
Publication &
\end{tabular}

Publication

- Pub. No: 486

- Subject No: 364.177 _ Author: Trebach, S.Arnold

Title of the New frontiers in drug policy / Arnold s.Trebach

Publication

Subject No: 362.293 Author: Harding, Geoffrey

Title of the opiate addiction, morality and medicine, from moral illness to

Publication pathological disease / Geoffrey Harding

Subject No: 615.788 - Author: International Narcotics Control Board

Title of the Psychotropic substances : statistics for 1987-/ INCB

Publication

Subject No: 614.1

Author: UN Div. of Narcotic Drugs

Title of the Recommended methods for testing barbiturate derivatives under

Publication international control : manual for use by national narcotics

Subject No: 614.1 Author: UN Div. of Narcotic Drugs

Title of the Recommended methods for testing peyote cactus (mescal buttons)

Publication / / mescaline and psilocybe mushrooms / psilocubin / UN Div. of

Subject No: 362.292 - Author: Kozlowski, T.IYnn

Title of the Research advances in : Alcohol and drug problems / University

Publication of Toronto

Subject No: 362.29 Author:

Title of the / Research findings on smoking of abused substances / National

Publication Institute on Drug Abuse

Pub. No: 489

Subject No: 362.29 Author:

Title of the Residual effects of abused drugs on behavior / National Institute

Publication on Drug Abuse

Subject No: 362.29 Author: Hewett, C.Paul

Title of the / straght talk about drugs / Paul c.Hewett

Publication

Subject No: 362.29 - Author: Daley, Dennisc

- Title of the / Surviving addiction workbook / Dennis c.Daley

Publication

Subject No: $\mathbf{3 7 1 . 1}$

Author: UNFDAC

Pub. No: 184

Pub. No: 424

Title of the

Publication

Teaching about drugs : Instruction manual / prepared for UN Fund

for Drug Abuse control 
- SUBJECT $=$ DRUGS

Subject No: 362.29 Author: Mcclure, Rowland Cynthia

- Title of the The courage to go on / Cynthia Rowland McCure Publication

Subject No: 345.0242 - Author: The Drug Policy Foundation

Pub. No: 487

Title of the The andean strategy reconsidered:Toward a sensible international

Publication drug policy / The Drug Policy Foundation

- Subject No: $\mathbf{1 5 . 7 8 8}$

Author: stimmel, Barry

Pub. No: 484

Title of the The facts about drug use : coping with drugs and alcohol in your

Publication family, at work, in your community / Barry stimmel, M.D.

- Subject No: 354.177 - Author: Trebach, S.Arnold Title of the The great issues of drug policy / Arnold s.Trebach Publication

- Subject No: 362.299 - Author: Morton, Ian K.M. Title of the Tranquilizers : The comprehensive guide / Ian K.M. Morton, John Publication Halliday, Judith M. Hall

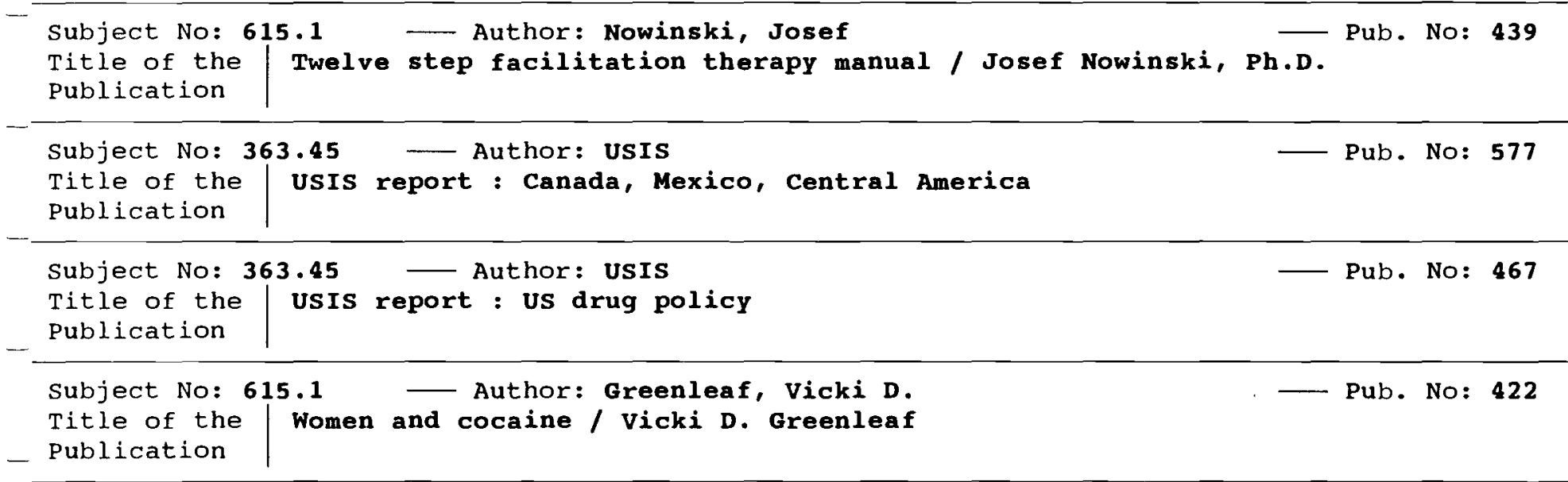


Subject No: 371.1 Author:

- Title of the 10 steps to help your child say "no" : a parents guide / NIAAA

Publication

Subject No: $371.1 \quad$ Author: UNo

Title of the A brief description of the manpower training program / Education

Publication sector support Project

- Subject No: 362.29 Author: Harrison-Burns, Bettye Pub. No: 378

Title of the A guide to multicultural drug abuse prevention

Publication

- Subject No: 615 Author: Julien, M.Robert

Title of the A primer of drug abuse / Robert M. Julien

Publication

- Subject No: 613

Author: Williams, Glen

Title of the All fo health : a resource book for Facts for life

Publication

Author: Bosch, Albert G.

Subject No: 630

Title of the Animal husbandry program 1991/ Albert G. Bosch

Publication

Subject No: 635

Author: Tsamparlis, Michael

Pub. No: 381

Title of the Apricot program / prepared by Michael Tsamparlis

Publication

Subject No: 630

Title of the

- Author: Saari, Eugene E.

Publication

Assessment of wheat production in Afghanistan and

reccommendations for future activities / prepared by Eugene E.

Subject No: 362.2937 Author:

Title of the Communications manual for drug abuse prevention programs

Publication / Asia Near East Regional Norcotics Education Program

Subject No: $371.1 \quad$ Author: PNCB

Title of the Community intervention against heroin abuse : Trainers manual

- Publication / PNCB

Subject No: 362.2937 Author:

Title of the

Community organization guide : A framework for community

involvement in drug abuse prevention / Division of substance

Publication

1 - Author: UNDCP

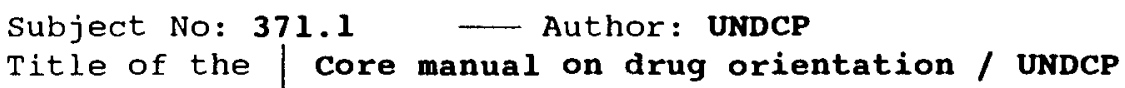

Publication

Subject No: 371.1 — Author: Thom Betsy

Pub. No: 603

- Title of the Development of materials, Methods and Techniques for drug

Publication

Awareness Creation Campaigns and Women's Training / Betsy Thom

Subject No: 630

Author: Altieri, Miguel

Pub. No: 219

\begin{tabular}{l|l} 
Title of the & Environmentally sound small scale agricultural projects : \\
Publication & Guidelines for planning / by Miguel Altieri ; edited by
\end{tabular} 
Subject No: 613 Author: UNICEF

Title of the Facts for life : a communication challange / UNICEF

Publication

Subject No: $361.77 \mathrm{M}$ Author: Buddenberg, D.

Title of the Final report on SSA (90-10759) to awareness creation compaign

Publication / D. Buddenburg

- Subject No: $361.77 \mathrm{M}$ - Author: Buddenberg, Doris

Title of the Final report on consultancy to project AFP/89/580: Master

Publication framework for training Afghan women / D. Buddenberg

- Subject No: 362.29 Author: Gay, Pat

Title of the Getting together : A study of self-help groups for drug users'

Publication families / Pat Gay

Subject No: 362.292 - Author: Children's Television Workshop (prepared - Pub. No: 360 Title of the Helping your child say no to alcohol / prepared by children's

Publication Television Workshop

Subject No: $371.1 \quad$ Author:

Title of the Helping your pre-team say "No" : a parents aid

Publication

Subject No: 060

Title of the International conference of NGos for drug abuse prevention,

Publication Karachi August 20-25, 1988 / PNCB

Subject No: $371.1 \quad$ Author: UNFDAC

Title of the Manual for resource poisons and community workers in drug abuse

Publication prevention / UN Fund for Drug Abuse Control

Subject No: 362.29 Author: UN Division of narcotic drugs

Title of the / Manual on drug abuse assessment / UN Division of Narcotic Drugs

Publication

Subject No: 362.2937 Author: UNDND

Title of the Manual on drug abuse assessment : Part 2, Use of population

- Pub. No: 375

Publication

surveys / UN Division of Narcotic Drugs

Subject No: 362.29 Author:

Title of the Manual on drug abuse prevention education and community

Publication information for teachers, community leaders and workers, media

Subject No: 371.1 Z Author: UNFDAC 265

Title of the Medical aspects of drug detoxification / prepared for UN Fund for

Publication $\mid$ Drug Abuse Control

Subject No: 361.7706 - Author: Operation Salam Pub. No: 587

- Title of the Mine clearance Programme for Afghanistan : Mid year report, 30

Publication June 1993 / by Operation Salam

Subject No: 361.7706 Author: Operation Salam

Title of the Mine awareness programme progress report July 1 - september 30 ,

Publication 1990 / Operation Salam 
- SUBJECT $=$ TRAINING

Subject No: 362.29207 Author: Lodi, Yusaf

- Title of the Narcotics control through cartoons / Yusaf Lodi

Publication

Subject No: 305.4 Author: May, Nicky

Pub. No: 122

Title of the No short cuts : A starter resource book for women's group field

Publication workers / Nicky May o the Networkers

Subject No: 307.72 Author: FAO

Title of the Participation in practice : Lessons from the FAo people's

Publication participation programme / FAO

Subject No: $302.2 \quad$ Author: Haaland, Ane

Title of the Pretesting communication materials with special emphasis o child

Publication health and nutrition education : A manual for trainers and

Subject No: 362.29 - Author: Frunkhouser, E.Judith \& Amatetti Low Pub. No: 3

Title of the | Prevention : From knowledge to action / prepared by Judith E.

Publication Funkhouser and sharon Low Amatetti

Subject No: 362.29 Author: UNDND

Title of the / Resource book of measures to reduce illicit demand for drugs

Publication

Subject No: 362.29 - Author: Millwood, David

Title of the Smart promotion / David Millwood and Helena Gezelius

Publication

Subject No: 362.29 Author: PNCB

Title of the Teachers drug orientation resource book / Pakistan Narcotics

Publication control Board

Subject No: $371.1 \quad$ Author: PNCB

Title of the Teachers drug orientation resource book / Pakistan Narcotics

Publication control Board

Subject No: 362.29 Author: PNCB

Title of the Teachers' guide to drug abuse prevention / PNCB

Pub. No: 213

Publication

Subject No: $371.1 \quad$ Author: UNFDAC

Title of the Teaching about drugs : Instruction manual / prepared for uN Fund

Publication for Drug Abuse Control

Subject No: $362.2937-$ Author: Flynn, stephen P.

Title of the Teaching about substance abuse : A resource manual for faculty

Publication

development / stephen P. Flynn, Ardis K. Davis,

Subject No: $371.1 \quad$ Author: DEA

- Title of the Team up for drug prevention with America's young athletes /

Publication Forest Hills school District

Subject No: 600

- Author: Sandhu, Ruby \& sandler Joanne (compileted

Pub. No: 121

Title of the The tech and tools book : A guide to technologies women are using

Publication worldwide / compiled by Ruby Sandhu and Joanne sandler 
AFG $/ 89 / 580$

LIST OF PUBLICATIONS IN ADCRP LIBRARY

- SUBJECT $=$ TRAINING

Subject No: 362.2937 Author: Alcohol and Drug Foundation

Publication

Subject No: 630

Three year strategic plan / Alcohol and Drug Foundation

Title of the

Author: FAO

Pub. No: 36

Publication

Training for agriculture and rural development 1989 - 1990 / Food

and Agriculture Organization

- Subject No: 362.2937 _ Author: United Nations Drug Control Programme

Title of the

Publication

Pub. No: 177

Subject No: 600 law enforcement officials / UN Drug Control Programme

Pub. No: 124

Title of the

Publication

Subject No: 362.29

Author: osap

Title of the

What you can do about drug use in America / OSAP

Pub. No: 311 


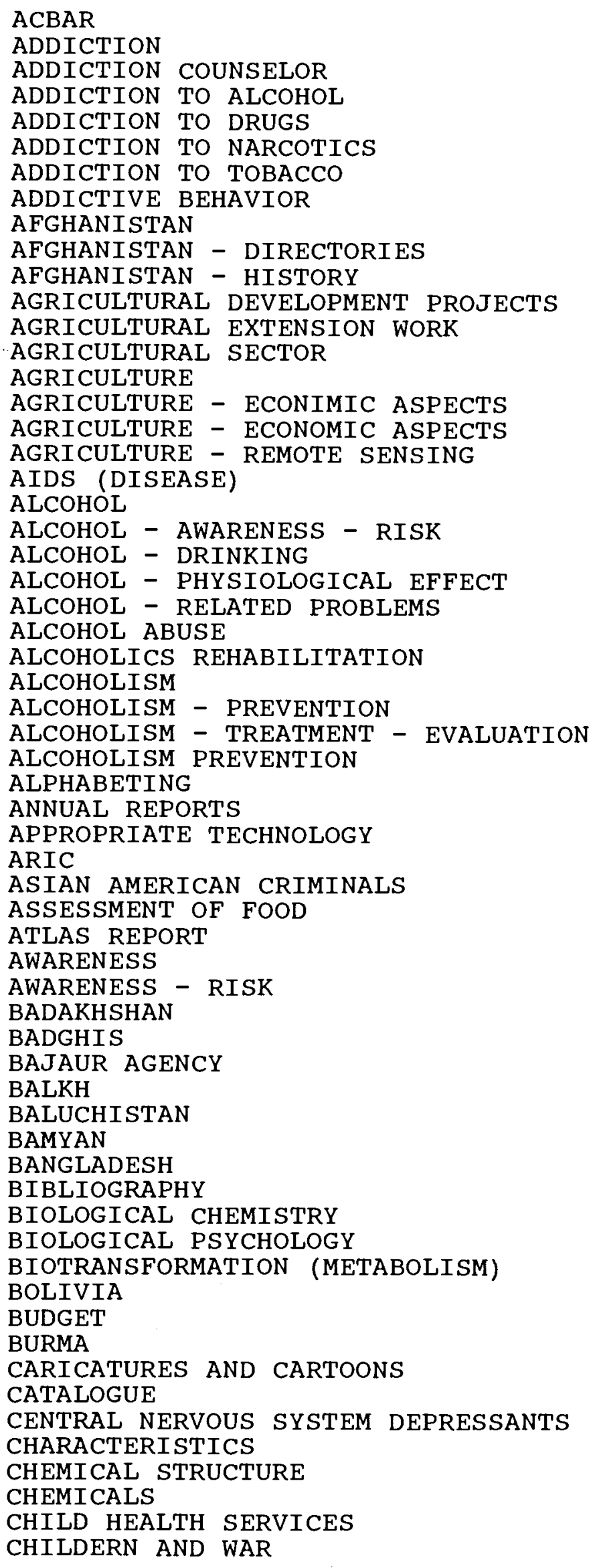


SUBJECT LIST

\begin{tabular}{|c|c|c|}
\hline & 62 & CHILDREN - CARE AND HYGIENE - EVELOPING \\
\hline & 63 & CHILDREN - DEVELOPING COUNTRIES - PERIODICALS \\
\hline & 64 & CHILDREN AND WAR \\
\hline \multirow[t]{3}{*}{-} & 65 & CLASSIFICATION \\
\hline & 66 & CLINICAL MEDICINE - RESEARCH \\
\hline & 67 & CLINICAL TRIALS OF DRUGS \\
\hline \multirow{4}{*}{-} & 68 & COCAINE \\
\hline & 69 & COCAINE ABUSE \\
\hline & 70 & COCAINE HABIT \\
\hline & 71 & COCAINE HABIT - RELAPSE - PREVENTION \\
\hline \multirow[t]{4}{*}{-} & 72 & COCAINE HABIT - TREATMENT \\
\hline & 73 & COLLECTION DEVELOPMENT (LIBRARIES) \\
\hline & 74 & COMMUNICATION \\
\hline & 75 & COMMUNITY DEVELOPMENT \\
\hline \multirow[t]{4}{*}{-} & 76 & COMMUNITY EDUCATION \\
\hline & 77 & COMPULSIVE BEHAVIOR \\
\hline & 78 & COMPUTER PROGRAMMES \\
\hline & 79 & CONCLUSION \\
\hline \multirow[t]{3}{*}{ - } & 80 & CONFERENCE PROCEED \\
\hline & 81 & CONFERENCE PROCEEDINGS \\
\hline & 82 & CONTROL OF \\
\hline \multirow[t]{4}{*}{-} & 83 & COORDINATION \\
\hline & 84 & COSTA RICA \\
\hline & 85 & COUNTRIES REPORTS \\
\hline & 86 & COUNTRY ACTIONS AGAINST DRUGS IN 1992 \\
\hline \multirow[t]{4}{*}{ - } & 87 & COUNTRY REPORTS \\
\hline & 88 & CRIME AND CRIMINALS \\
\hline & 89 & CROP PROTECTION \\
\hline & 90 & CROP SUBSTITUTION \\
\hline \multirow[t]{3}{*}{ - } & 91 & CROPS \\
\hline & 92 & CULTIVATION \\
\hline & 93 & CURRICULUM PLANNING \\
\hline \multirow[t]{4}{*}{-} & 94 & DACAAR \\
\hline & 95 & DAI \\
\hline & 96 & DATABASE \\
\hline & 97 & DEMAND REDUCTION \\
\hline \multirow[t]{4}{*}{-} & 98 & DEVELOPING COUNTRIES \\
\hline & 99 & DIR \\
\hline & 100 & DIRECTORS MEETING \\
\hline & 101 & DISCRIMINATION IN CRIMINAL JUSTICE ADMINIST- \\
\hline \multirow[t]{4}{*}{-} & 102 & DRAMA \\
\hline & 103 & DRUG - ALCOHOL INTERACTIONS \\
\hline & 104 & DRUG - SIDE EFFECT \\
\hline & 105 & DRUG - SIDE EFFECTS \\
\hline \multirow{3}{*}{ - } & 106 & DRUG - THERAPY \\
\hline & 107 & DRUG - TOXICOLOGY \\
\hline & 108 & DRUG ABUSE \\
\hline \multirow[t]{4}{*}{ - } & 109 & DRUG ABUSE - BIBLIOGRAPHY \\
\hline & 110 & DRUG ABUSE - PREVENTION \\
\hline & 111 & DRUG ABUSE - STUDY \& TEACHING \\
\hline & 112 & DRUG ABUSE - STUDY AND TEACHING \\
\hline \multirow[t]{3}{*}{-} & 113 & DRUG ABUSE - TREATMENT \\
\hline & 114 & DRUG ABUSE - TREATMENT - EVALUATION \\
\hline & 115 & DRUG ABUSE AND CRIME \\
\hline \multirow[t]{7}{*}{ - } & 116 & DRUG ABUSE PREVENTION \\
\hline & 117 & DRUG ABUSE STUDY - STUDY AND TEACHING \\
\hline & 118 & DRUG ABUSE STUDY AND TEACHING \\
\hline & 119 & DRUG AND MASS MEDIA \\
\hline & 120 & DRUG ANTAGONISM \\
\hline & 121 & DRUG AWARENESS \\
\hline & 122 & DRUG CONTROL \\
\hline
\end{tabular}


SUBJECT LIST

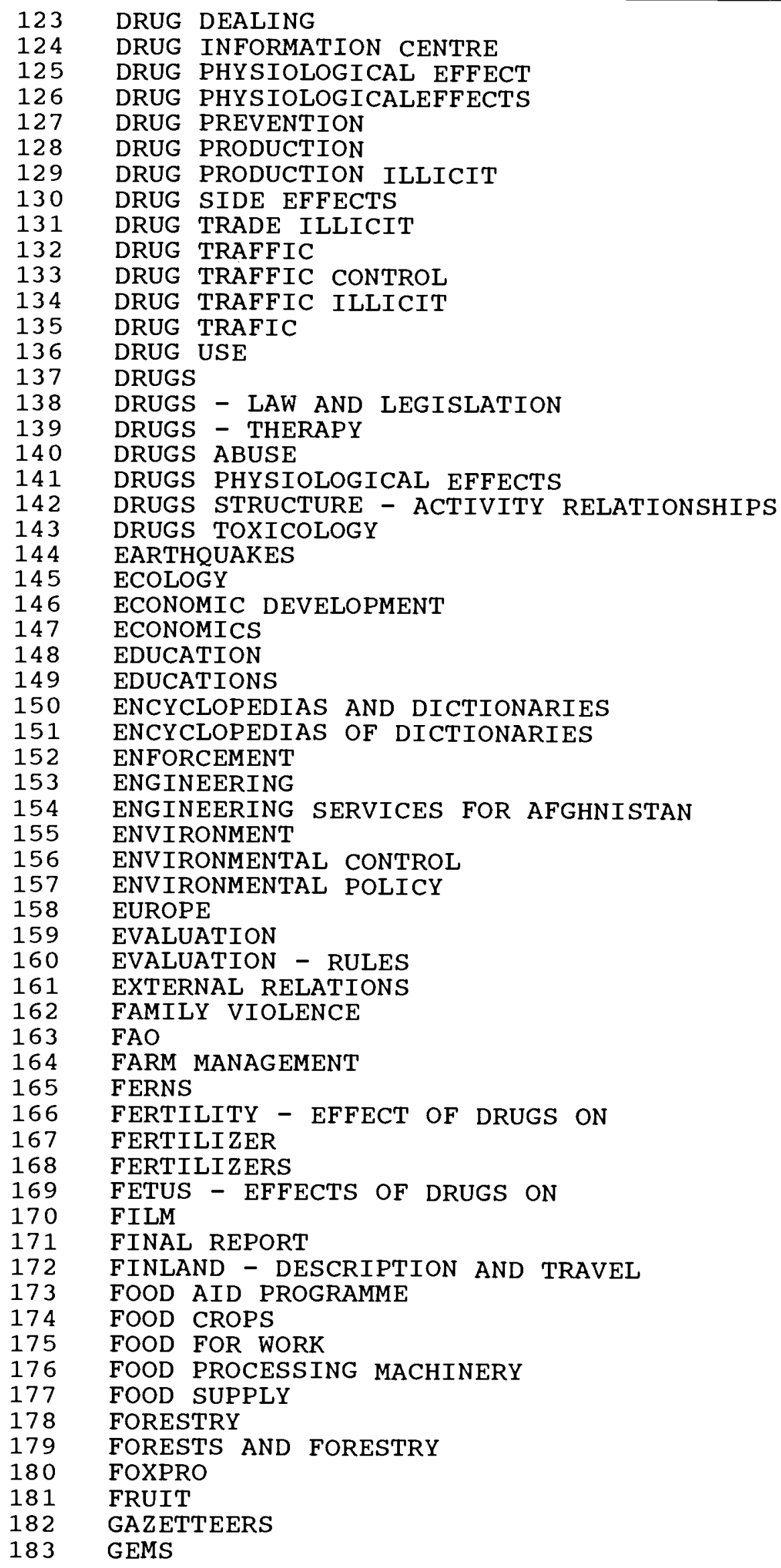




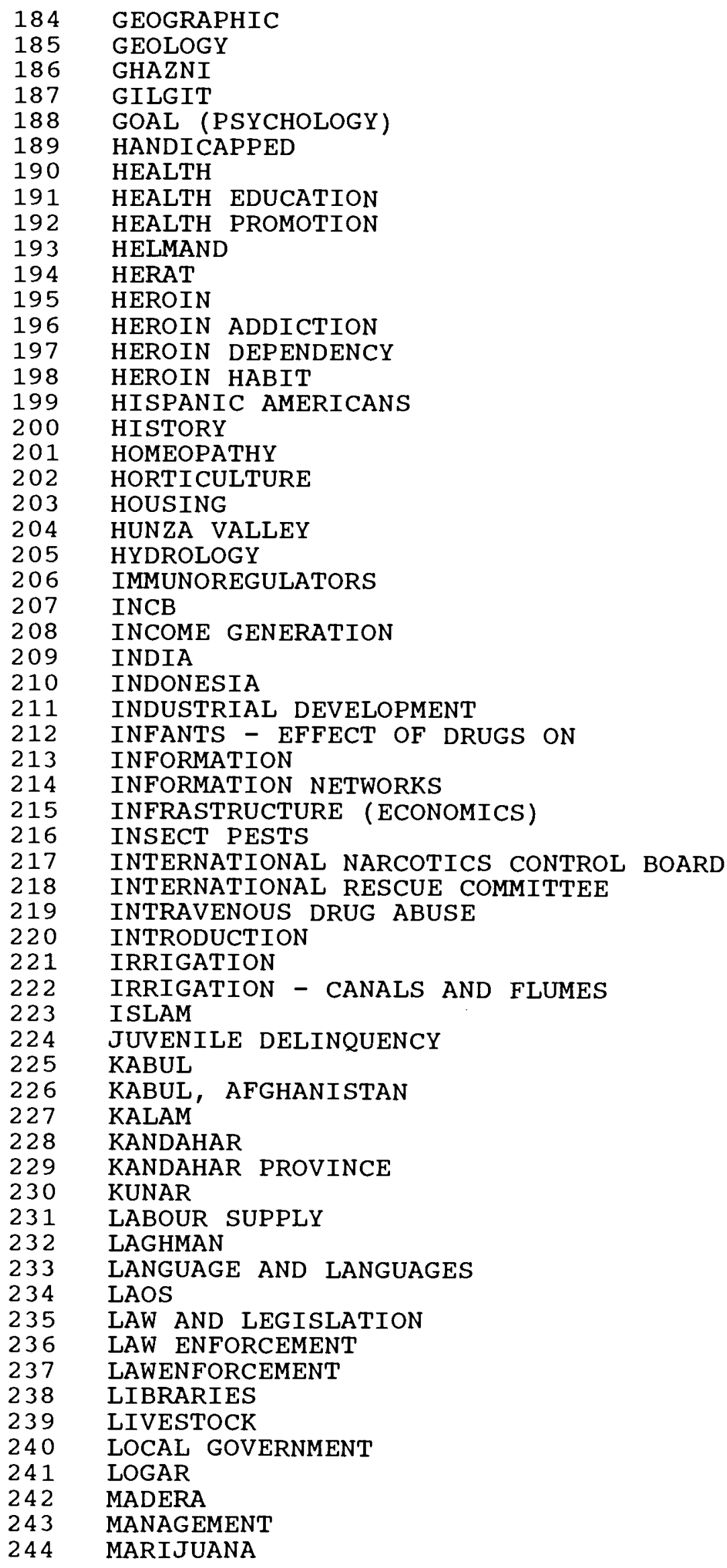


SUBJECT LIST

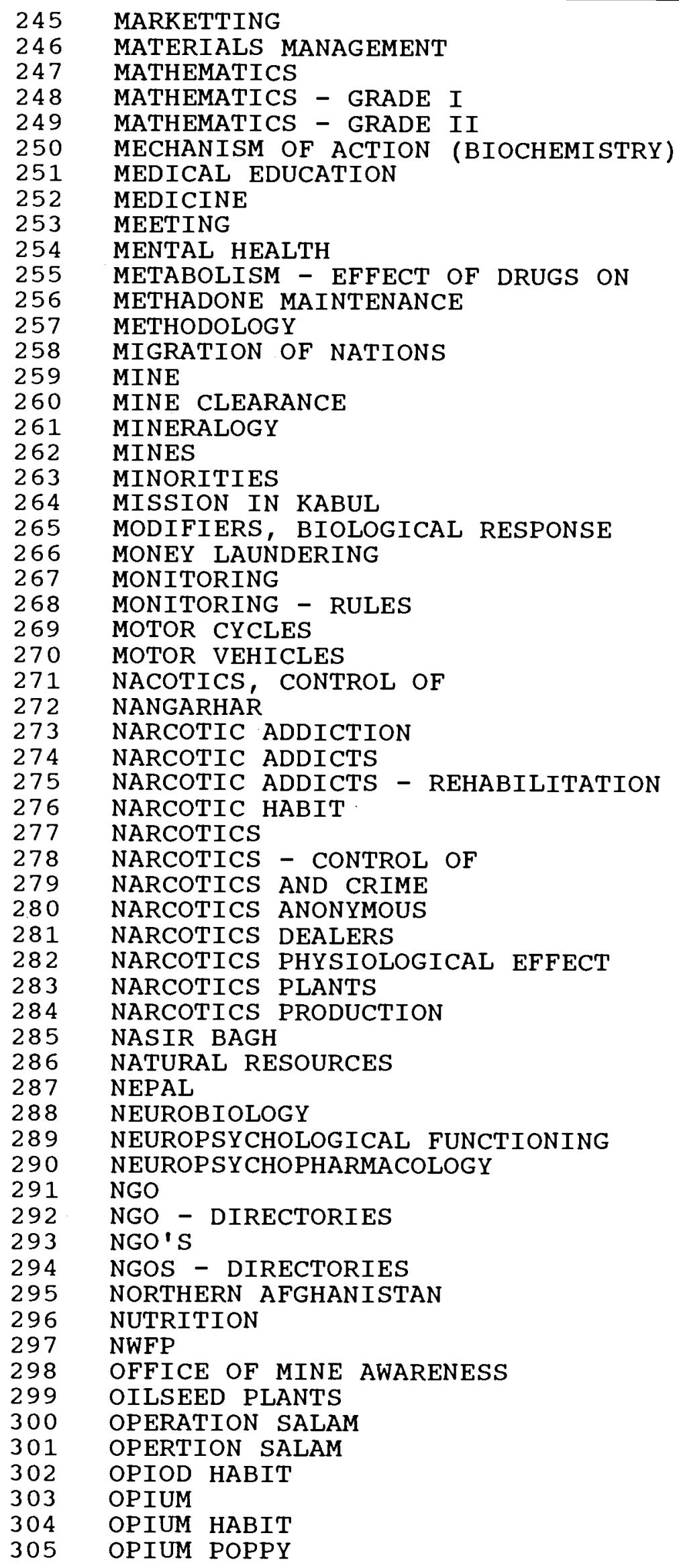


SUBJECT LIST

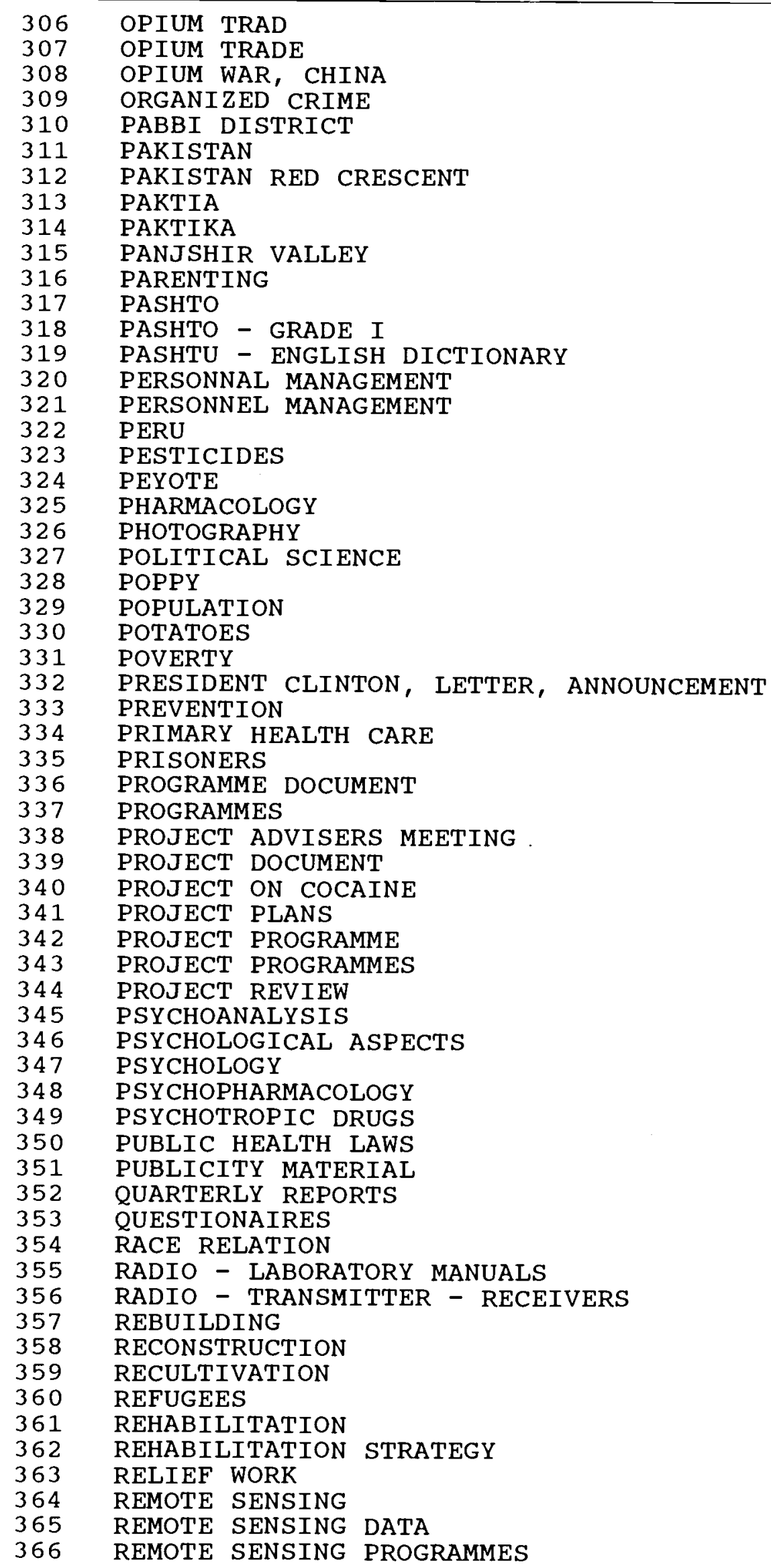


SUBJECT LIST

367

368

369

370

371

372

373

374

375

376

377

378

379

380

381

382

383

384

385

386

387

388

389

390

391

392

393

394

395

396

397

398

399

400

401

402

403

404

405

406

407

408

409

410

411

412

413

414

415

416

417

418

419

420

421

422

423

424

425

426

427
REPATRAITION

REPATRIATION

RESEARCH

RESOURCES

RICE

RONCO

RUAL DEVELOPMENT

RURAL CONDITIONS

RURAL DEVELOPMENT

RURAL DEVELOPMENT PROJECTS

SAMANGAN

SEEDS

SELF - HELP GROUP

SOCIAL ROLE

SOCIAL WORK WITH ALCOHOLICS

SOIL CONSERVATION

SOUTH ASIA

SPACE ATMOSPHERE

SPACE ENVIRONMENT

SRI LANKA

STATISTICS

STRATEGY DOCUMENT

STREET CHILDREN

SUBPROJECT PERFORMANCE

SUBSTANCE ABUSE

SUBSTANCE ABUSE - GENETIC ASPECTS

SUBSTANCE ABUSE - GOVERNMENT POLICY - US

SUBSTANCE ABUSE - IN ADOLESCENCE

SUBSTANCE ABUSE - POPULAR WORKS

SUBSTANCE ABUSE - PREVENTING AND CONTROL

SUBSTANCE ABUSE - PSYCHOLOGY

SUBSTANCE ABUSE - RELAPSE - PREVENTION

SUBSTANCE ABUSE - THERAPY

SUBSTANCE ABUSE - TREATMENT

SUBSTANCE DEPENDENCE - REHABILITATION

SUBSTANCE DEPENDENCE - THERAPY

SUBSTANCE DEPENDENCE REHABILITATION

SUBSTANCE DEPENDENCE THERAPY

SURGERY

SURVEYS

SWEDISH COMMITTEE FOR AFGHANISTAN

TAJIKISTAN

TEACHING

TECHNICAL ASSISTANCE

TECHNICAL INOVATIONS

TECHNICAL MANUALS

TECHNOLOGY

TECHNOLOGY ASSESSMENT

THAI-HIGHLAND PROJECT

THAILAND

THERAPEUTIC COMMUNITY

TOBACCO

TOBACCO - HABIT

TOXICOLOGY

TRAINING

TRAINING MANUALS

TRAINING MATERIALS

TRANQUILLIZING DRUGS

TRANSPORT

TRANSQUILLIZING DRUGS

TRAQUILLIZING DRUGS

Produced on 30/01/94 at 14:57:09 
Afghanistan Drug Control and Rehabilitation Programme

SUBJECT LIST

428 TRAVEL WRITING

429 TREATMENT

430 TRIBAL AREAS

431 TURKEY

432 UN

433 UNDCP

434 UNDP/OPS

435 UNFDAC

436 UNITED NATIONS

437 UNITED NATIONS

439 UNITED STATES

CHILDREN'S FUND

440 URDU

441 US POLICY INITIATIVES AND PROGRAMMES

442 USA

443 VEGETABALES

444 VEGETABLES

445 VERTIVER

446 VITICULTURE

447 WARDAK

448 WATER

449 WATERSHED MANAGEMENT

450 WEEDS - CONTROL

451 WHEAT

452 WID

453 WOMEN - MENTHAL HEALTH

454 WOMEN IN DEVELOPMENT

455 WOMEN IN EDUCATION

456 WOMEN'S TRAINING

457 WORK PLAN

458 WORKING PAPERS

459 YOUTH - DRUG ABUSE

460 YOUTH - DRUG USE

461 YOUTH EDUCATION

462 ZABUL

463 ZOPP 